\title{
Reconfiguring Assimilation: Understanding the First Nations Property Ownership Act in Historical Context
}

\section{By:}

\author{
Kanatase Horn
}

A thesis submitted to the Faculty of Graduate and Postdoctoral Affairs in partial fulfillment of the requirements for the degree of

Master

in

School of Canadian Studies

Carleton University

Ottawa, Ontario

(C) 2013

Kanatase Horn 
Library and Archives

Canada

Published Heritage

Branch

395 Wellington Street

Ottawa ON K1A ON4

Canada
Bibliothèque et

Archives Canada

Direction du

Patrimoine de l'édition

395 , rue Wellington

Ottawa ON K1A ON4

Canada
Your file Votre référence

ISBN: 978-0-494-94603-9

Our file Notre référence

ISBN: $978-0-494-94603-9$
NOTICE:

The author has granted a nonexclusive license allowing Library and Archives Canada to reproduce, publish, archive, preserve, conserve, communicate to the public by telecommunication or on the Internet, loan, distrbute and sell theses worldwide, for commercial or noncommercial purposes, in microform, paper, electronic and/or any other formats.

The author retains copyright ownership and moral rights in this thesis. Neither the thesis nor substantial extracts from it may be printed or otherwise reproduced without the author's permission.
AVIS:

L'auteur a accordé une licence non exclusive permettant à la Bibliothèque et Archives Canada de reproduire, publier, archiver, sauvegarder, conserver, transmettre au public par télécommunication ou par l'Internet, prêter, distribuer et vendre des thèses partout dans le monde, à des fins commerciales ou autres, sur support microforme, papier, électronique et/ou autres formats.

L'auteur conserve la propriété du droit d'auteur et des droits moraux qui protege cette thèse. $\mathrm{Ni}$ la thèse ni des extraits substantiels de celle-ci ne doivent être imprimés ou autrement reproduits sans son autorisation.
In compliance with the Canadian Privacy Act some supporting forms may have been removed from this thesis.

While these forms may be included in the document page count, their removal does not represent any loss of content from the thesis.
Conformément à la loi canadienne sur la protection de la vie privée, quelques formulaires secondaires ont été enlevés de cette thèse.

Bien que ces formulaires aient inclus dans la pagination, il n'y aura aucun contenu manquant. 


\begin{abstract}
This thesis critically analyzes the First Nations Property Ownership Act (FNPOA), a developing piece of federal legislation that is based on the arguments contained in the book, "Beyond the Indian Act: Restoring Aboriginal Property Rights." The FNPOA, if enacted by Parliament in 2013, would permit participating First Nations communities to establish a private property regime within the reserve's boundaries in order to facilitate economic development. This thesis asks all First Nations leaders to reject the FNPOA if it is enacted due to its similarities to the White Paper of 1969 , in that both can lead to assimilation, as well as its potential to lead to the dispossession of Indigenous people from their land base. While this thesis acknowledges that there are minor differences between the FNPOA and the White Paper, their end results would be the same: fulfilling Indian policy's long term goal, which is to eliminate the reserve system and turn Indigenous people into land owning citizens as a way to eliminate the Crown's expensive fiduciary duty.
\end{abstract}




\section{Acknowledgements}

I would like to provide a big nie:wen kowa (thank you very much) to Dr. Donna Patrick for believing in me when I first approached you two years ago with my research idea, and setting me on the right path. I would also like to provide Dr. Siomonn Pulla with a big nie:wen kowa for all of your support, whether it was providing me with a resource, or meeting me for coffee to discuss my research. Both you and Donna helped me so much, and I really appreciate all you've done! Nie:wen! I would like to say nie:wen kowa to Dr. Michel Hogue as well for being the external reader. I really appreciate it! To everyone in the School of Canadian Studies who has helped me during my time in the department, I would also like to say nie:wen kowa!

I would also like to thank my partner Tania, who has supported me throughout this whole academic journey. We shared our ups and downs, but most importantly, we welcomed our son into this world in June 2012! Tania, I would like to say nie:wen kowa for all of your support- I couldn't have done this without you! And konoronhkwa!

Finally, I would like to say nie:wen kowa to the Kahnawake Education Centre for providing me with support, and being understanding throughout my entire educational career.

To all my relations: Nie:wen kowa! 


\section{Dedication}

This thesis is dedicated to my son, Kahrhi:io. You showed me what it means to be Onkwehonwe. I love you. 


\section{Table of Contents}

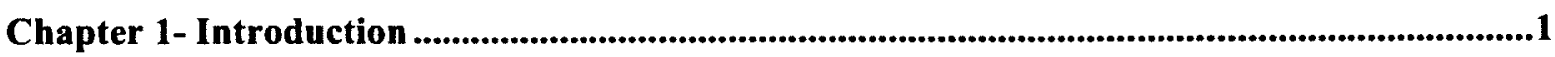

PART 1: The FNPOA, Research Questions, and Thesis Statement ...........................................

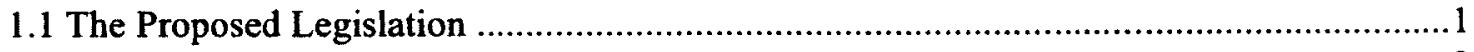

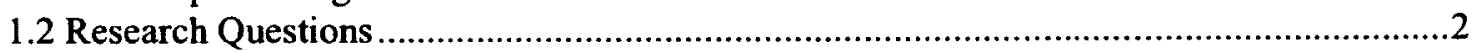

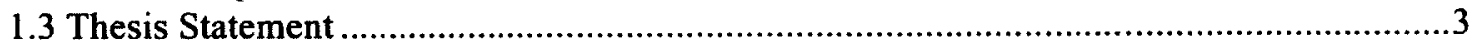

PART 2: Methodology and Thesis Structure

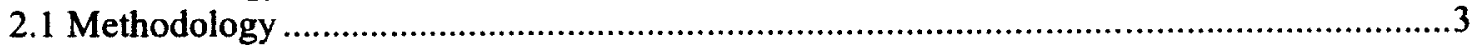

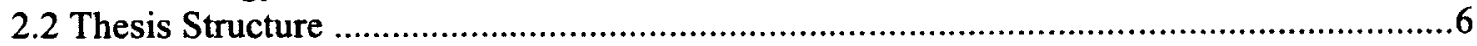

Chapter 2: Literature Review and Historical Analysis...............................................................8

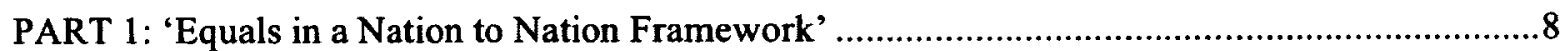

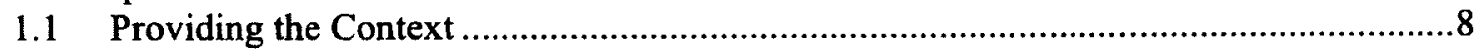

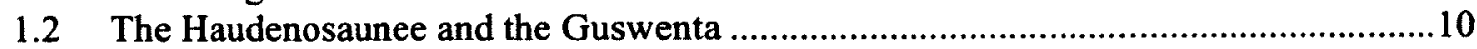

1.3 The Royal Proclamation of 1763: Nation to Nation? ...............................................12

PART 2: 'Defining and Civilizing the Indian Problem' ........................................................17

2.1 Shifting Imperial Relations: Early $19^{\text {th }}$ Century Paradigms of Assimilation ..................17

2.2 The Bagot Commission: Towards an Integrated Indian Policy ......................................22

2.3 Consolidating Aggressive Polices of Assimilation: Towards the 1876 Indian Act.........25

PART 3: 'Eliminating the Indian Problem' ....................................................................27

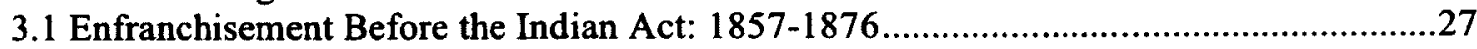

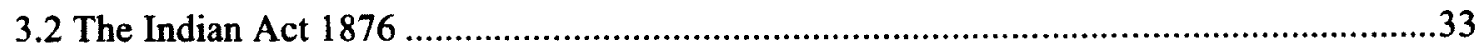

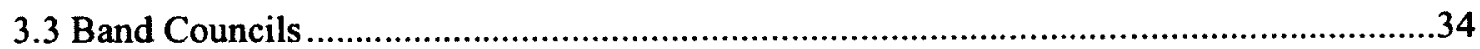

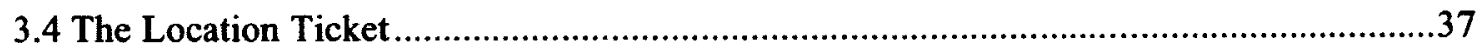

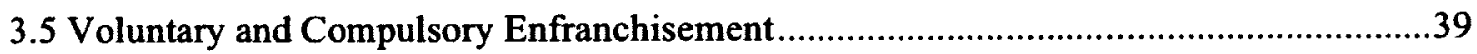

3.6 Community Wide Enfranchisement..................................................................42

Chapter 3- The White Paper and the FNPOA ........................................................................44

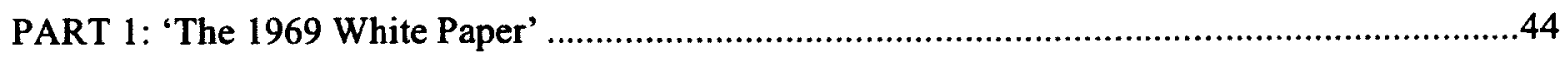

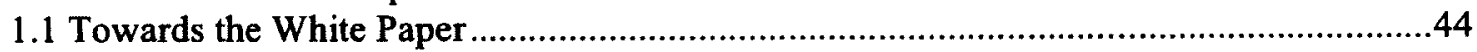

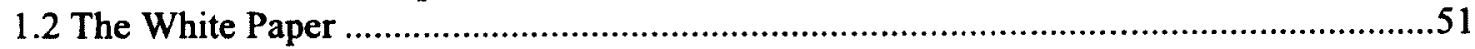

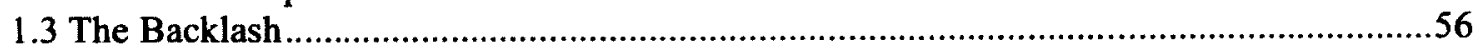

PART 2: On and Off Reserve Property Rights................................................................58

2.1 Land Tenure On First Nations Reserves: An Overview .........................................58

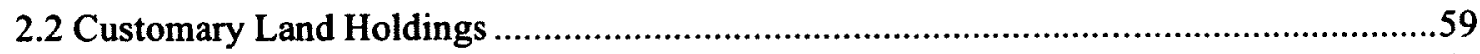

2.3 Permits, Designations, and Individual Leases .........................................................61

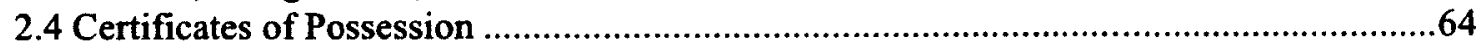

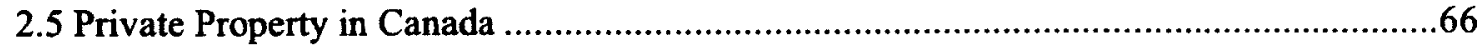

PART 3: The Proposed First Nations Property Ownership Act ...........................................69

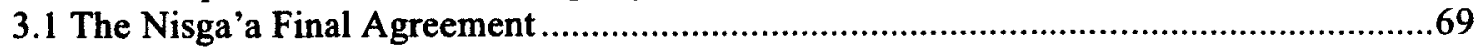

3.2 The First Nations Property Ownership Act ......................................................

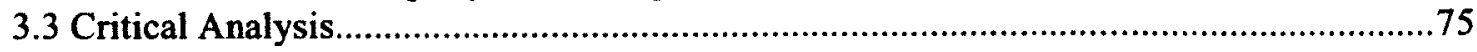


Chapter Four: Summary of Findings and Recommendations ..............................................82

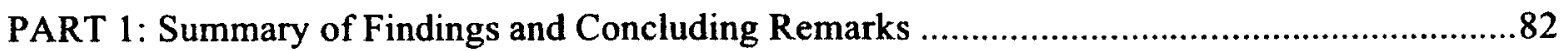

1.1 The Evolution of my Rationale to Complete this Project .........................................82

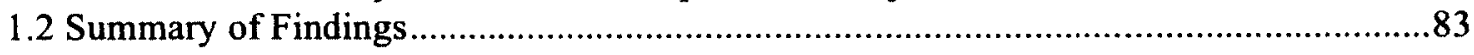

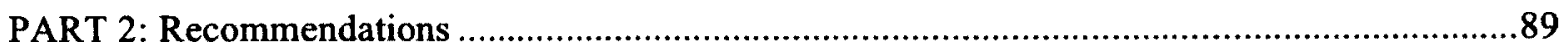

2.1 The Mohawk Prophecy of the Two Headed Snake.................................................89

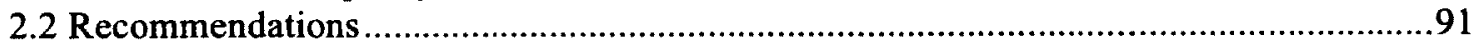

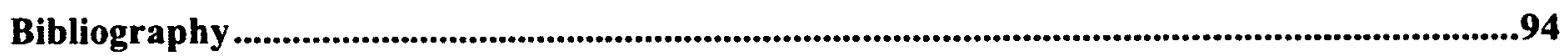




\section{Chapter 1- Introduction}

\section{PART 1: The FNPOA, Research Questions, and Thesis Statement}

\subsection{The Proposed Legislation}

The First Nations Property Ownership Act (referred to throughout this thesis as the FNPOA) is a developing, soon to be proposed, piece of federal legislation that is being spearheaded by First Nations leader Manny Jules in collaboration with the Department of Aboriginal Affairs and Northern Development Canada. It is based on the ideas found in the book, Beyond the Indian Act: Restoring Aboriginal Property Rights, which was coauthored by Tom Flanagan, Christopher Alcantara, and Andre Le Dressay.

The FNPOA will be introduced for debate this year, and if enacted, it would allow First Nations communities that choose to adopt it to grant their community members fee simple/private property rights. This is a key aspect of the FNPOA, although it would operate in conjunction with its other defining feature: the legislation would transfer underlying title from the Crown in the right of the province, to any participating First Nations community. This is supposed to prevent a First Nations' land base from being eroded via expropriation, since regardless of who possesses legal interests to the land, or how they came to acquire them, the underlying/reversionary title would always remain with the Indigenous government. According to its developers, with underlying/reversionary title, a First Nations government could extend and guarantee a 
community member's fee simple property rights without fear that federal, provincial, or other third party interests will expropriate their land, and thus erode their land base. ${ }^{1}$

\subsection{Research Questions}

In Indian country, no other legislation, or proposed piece of Indian policy is as well known as the White Paper of 1969 . Due to its intention to unilaterally eliminate the federal government's fiduciary duty to Indigenous people, as well as to introduce private property to Indigenous communities, ${ }^{2}$ the White Paper has reached such a level of infamy in Indian country, that the mere mention of its name can shut down discussions, even when a comparison between the policy in question and the White Paper is unwarranted.

But what happens when a comparison between the proposed policy and the White Paper is legitimate? What happens when a proposed policy not only contains the same elements as the White Paper, but is also being justified by its developers for the same reasons? What should Indigenous leaders demand the federal government do? On the other hand, what if Indigenous leaders are unaware of the similarities? Should they be made aware, or should they be left alone to make the decisions on their own, for better or worse?

I believe that a First Nations government should have the self-determining authority to make their own political and economic decisions; this is an inherent right they possessed prior to colonization, and it is a right that they still possess today. However, I also think it sets a dangerous precedent when a community enters into a new

\footnotetext{
${ }^{1}$ Tom Flanagan, Christopher Alcantara, and Andre Le Dressay, Beyond the Indian Act: Restoring Aboriginal Property Rights (Montreal-Kingston: McGill-Queen's University Press, 2010), 5.

${ }^{2}$ Government of Canada, Statement of the Government of Canada on Indian Policy 1969, Report on Indian Policy (Ottawa: Government of Canada, 1969), 7.
} 
legislative jurisdiction without fully understanding the risks associated with doing so. In light of this, my thesis will set out to answer one central research question, which is: why should Indigenous leaders resist and reject the proposed First Nations Property Ownership Act?

\subsection{Thesis Statement}

Because the First Nations Property Ownership Act's promise of underlying/reversionary title is appealing, and might encourage Indigenous leaders to overlook its potential flaws, particularly in light of its similarities to the White Paper of 1969 , this thesis will answer my research question in a fairly straightforward manner. Therefore, my thesis statement is: Indigenous leaders must reject the FNPOA due to its similarities with the White Paper of 1969; both of these government legislations promote assimilation, and both can lead to the erosion of an Indigenous community's land base despite the developers' claim that First Nations underlying title is inalienable.

\section{PART 2: Methodology and Thesis Structure}

\subsection{Methodology}

Considering the purpose of this thesis is to provide native leaders, whether they are band councilors or traditional/cultural leaders, with accurate information to guide their decision as to whether their communities should adopt or reject the FNPOA, this thesis will take an interdisciplinary approach, and rely on different resources that come from a variety of intellectual and academic disciplines. For instance, considering this thesis is to 
act as a critical analysis of a policy proposal, I will rely on scholarship from the legal community, as well as other public policy papers that discuss on-reserve property rights.

However, considering my critique will also involve a lengthy historical analysis to discredit the FNPOA, I will also need to utilize various historical resources so that I can describe the more general relationship between Indigenous people, private property, and assimilation. These resources will help me describe the linkages between assimilation and private property that started to emerge in the early nineteenth century, and culminated with the White Paper in 1969. With that said, I must remember that in order for this thesis to appeal to Indigenous leaders in a culturally relatable way, I must frame my arguments, articulate my thoughts, and interpret this entire project through a very specific analytical lens, which I refer to as a critical Indigenous perspective, which in an academic context, requires Indigenous academics to challenge the legacy and ongoing colonization of Turtle Island. ${ }^{3}$ Ultimately, while this kind of academic pursuit is unique due to its interdisciplinary approach, as well as the fact $\mathrm{I}$ have provided myself with a narrow thesis statement, it is not without precedent.

For example, Dale Turner critiqued various policies and interpretations of Aboriginal rights in his book, This is not a Peace Pipe: Towards a Critical Indigenous Philosophy. While Turner did not critically explore a developing piece of legislation in the same way this thesis is doing, he did critically analyze and discuss the White Paper of 1969, which he described as woefully ill-conceived, and that it was primarily motivated

\footnotetext{
${ }^{3}$ Taiaiake Alfred, "Warrior Scholarship: Seeing the University as a Ground of Contention," in Indigenizing the Academy: Transforming Scholarship and Empowering Communities, by Devon A. Mihesuah and Angela Wilson (editors) (Lincoln: University of Nebraska Press, 2004 ), 92.
} 
by the desire to get out of the expensive "Indian business. ${ }^{, 4}$ Another resource that is useful, if only due to its discussion on Indigenous policy-making, is the article entitled, "Indigeneity-Grounded Analysis (IGA) as Policy (Making) Lens: New Zealand Models, Canadian Realities.”

Co-written by Maori scholar Roger Maaka, and University of Waterloo professor Augie Fleras, this article describes a way to not only create public policy that positively affects Indigenous people, but also how to interpret and analyze pre-existing policies. While their article is primarily dedicated to providing practical tools and lenses to create better Aboriginal policy, they do make an important statement on public policy in general, which is useful to this thesis. According to Fleras and Maaka:

Neither policy nor policy making are neutral or value free. Rather, as socially constructed conventions, policy and policy-making are loaded with dominant values, Eurocentric ideals, and vested interests. So systemically embedded are notions about what is normal, desirable, or acceptable with respect to policy design, underlying assumptions, priorities and agenda, and process that even institutional actors are rarely aware of the logical consequences by which some are privileged, others excluded. $^{s}$

This idea became particularly important when they discussed the need for Indigenous participation in the policy-making process, since they suggest that when Indigenous people do not participate in policy creation, dominant values, biases, and assumptions go unchecked, which results in the maintenance of the status quo. ${ }^{6}$

In regards to the FNPOA, despite the fact Manny Jules, himself an Indigenous person from British Columbia, is helping develop this legislation, Maaka and Fleras' words could not be any truer, considering that its developers (Jules included) assume that

\footnotetext{
${ }^{4}$ Dale Turner, This is not a Peace Pipe: Towards a Critical Indigenous Philosophy (Toronto: University of Toronto Press, 2006), 21.

${ }^{5}$ Roger Maaka and Augie Fleras, "Indigeneity-Grounded Analysis (IGA) as Policy (-Making) Lens: New Zealand Models, Canadian Realities," The International Indigenous Policy Journal (2010): 2.

${ }^{6}$ Fleras and Maaka, "Indigeneity Grounded Analysis as Policy (-Making) Lens," 3.
} 
Indigenous people want to become land owning, tax paying citizens of Canada. ${ }^{7}$ While this is troubling in its own right, it becomes even more problematic when one realizes that this assumption, when viewed in light of Canadian history, is actually not new, and formed the basis of Indian policy for well over one hundred years. This is why my analysis of the FNPOA is so highly dependent on analyzing the history of private property in relation to Indigenous peoples and their communities.

\subsection{Thesis Structure}

The next three chapters of this thesis will unfold chronologically, beginning with the second chapter, which will discuss the history of Indian policy leading up to the White Paper of 1969. However, the second chapter will begin with a discussion leading up to the nineteenth century, a period of time the Royal Commission on Aboriginal Peoples refers to as 'contact and cooperation.' While this discussion will be brief, it will serve two primary functions. The first will be to demonstrate how far the nation-to-nation relationship deteriorated by the 1830 s, when Indian policy shifted towards 'civilizing' Indians so they could function in an emerging Euro-Canadian culture. The other key reason for this discussion will be to provide my third and fourth chapters with a point of reference when I discuss the various times when Indigenous people asked the Canadian state to return to their former political relationships, which were defined by respect and non-interference.

After this, the chapter will lead into a discussion on the development and consolidation of Indian policy in the nineteenth century into the twentieth century. It will discuss the paradoxical nature of the Indian Act, with its assimilatory provisions, as well

\footnotetext{
${ }^{7}$ Flanagan, Alcantara, and Le Dressay, Beyond the Indian Act, 3-5.
} 
as its protective mechanisms. This discussion will focus on the Indian Act's assimilatory provisions, including the institutions it introduced to bands, which were meant to gradually indoctrinate with Euro-Canadian values. However, enfranchisement will be a primary focus of this chapter, since it included stipulations that outlined how an individual Indian who was enfranchised shed their Indian status and often received a plot of reserve land in fee simple. This chapter will end with an analysis of community wide enfranchisement provisions within the Indian Act, which enfranchised entire communities. Ultimately, the purpose of the second chapter is to contextualize the third chapter, since I am arguing that the White Paper was not a necessarily a continuation of Indian Act policy, but instead an attempt to finish what the Indian Act tried to do: assimilate Indian people.

After the second chapter, my third chapter will discuss both the White Paper of 1969 and the proposed First Nations Property Ownership Act. It will include an analysis of the White Paper, including its technical elements as well as it ideological assumptions. From there, the chapter will shift its focus and discuss on-reserve property rights under the Indian Act, as well as a brief discussion of fee simple property rights. This discussion will provide my analysis of the FNPOA with the appropriate context, since the FNPOA is designed to give participating First Nations communities the chance to escape the Indian Act's property rights framework. ${ }^{8}$ The second chapter will end with a discussion on the First Nations Property Ownership Act as it is described in the book, Beyond the Indian Act. This will include an analysis of the proposed legislation's technical components, but more importantly, it will include my critical analysis, which is directed towards Indigenous leaders, and in a very real sense will reaffirm my thesis statement.

\footnotetext{
${ }^{8}$ Flanagan, Alcantara, and Le Dressay, Beyond the Indian Act, 29.
} 
My fourth and final chapter will include a summary of findings, and will end with my recommendations that will be directed towards Indigenous leaders, and Indigenous academics.

\section{Chapter 2: Literature Review and Historical Analysis}

\section{PART 1: 'Equals in a Nation to Nation Framework'}

\subsection{Providing the Context}

Before this chapter starts to discuss the history of private property and First Nations communities, I need to briefly address a few issues that need to be clarified. Most importantly, I should reiterate that the core purpose of this thesis is to provide Indigenous leaders and the communities they represent with an extensive, yet practical basis to reject the proposed First Nations Property Ownership. Quite simply, this thesis argues that the main reason why the FNPOA needs to be rejected is due to its striking similarity to the White Paper of 1969, which I might add, was immediately rejected in 1969-70. However, the purpose of this specific chapter is not to highlight those similarities, since my third chapter will address those issues later on.

Instead, the purpose of this second chapter is to explore the colonial history leading up to the White Paper, which includes the creation of reserves and residential schools, as well as the introduction of Euro-Canadian concepts, such as municipal government structures, voting, and individual land tenure. While this thesis does not discuss residential schools for the sake of space and time, the other institutions that were just mentioned represent the tools that were supposed to engender Indians with the desire 
to voluntary assimilate/enfranchise, which would have initiated the erosion of the reserve system, since enfranchised Indians would have received a plot of reserve land in fee simple.

As this chapter will illustrate, the erasure of the reserve system did not occur, since Indigenous communities largely resisted these western institutions and concepts, and more importantly, resisted legal enfranchisement. Therefore, the White Paper in light of this historic resistance was an attempt to circumvent the collective will of Indigenous people, and fulfill the Indian Act's long-term goal: the complete cultural and legal assimilation of Indigenous people. In other words, the White Paper was not a continuation of Indian Act policy, but rather an attempt to accomplish what the Indian Act tried to do: eliminate the 'Indian problem.' This would suggest that the FNPOA, due to its similarity to the White Paper, is also an attempt to eliminate Indigenous people as a social and legal fact, and should therefore raise the same kind of resistance that the White Paper generated.

But in order to get to that point in the discussion, this chapter needs to establish the historic trajectory of the colonial government's attempt to eliminate Indigenous people and the protected status of their reserve lands. That is the point of this chapter. However, this chapter has a secondary purpose as well, which is to discuss, if only briefly, the period of time the Royal Commission on Aboriginal Peoples describes as 'contact and cooperation.' This is an important period of time to discuss, considering that most of the agreements/treaties of peace and friendship that Indigenous nations not only negotiated, but also still consider binding, were entered into in this time frame. It is my contention that discussing this history will demonstrate how far the nation-to-nation relationship 
deteriorated by the time the British Crown began to implement its assimilatory agenda in the nineteenth century.

Nonetheless, this is a vast period of time to try and adequately cover, so to narrow it down into a more manageable topic, I will discuss the experience of the Haudenosaunee, since it was their agreement they made with the Dutch/British- the TwoRow Wampum- that lived on over the centuries, being brought up at discussions after the Royal Proclamation of 1763 was declared, and even into the nineteenth century. ${ }^{9}$

\subsection{The Haudenosaunee and the Guswenta}

The Mohawks, who are one of the five original members of the Iroquois Confederacy, occupied the "eastern door" and were the first member of the Confederacy to engage with Dutch traders in the early seventeenth century. Like most early European/native relationships, this relationship was based on commercial interest, and in $1613,{ }^{10}$ the two parties agreed to the terms of the Two-Row Wampum, or gusweta, as it is known in the Mohawk language. Like most agreements at the time, the agreement was codified in a wampum belt, and its design was a visual representation of its actual meaning. Mike Mitchell of Akwesasne describes it and states,

There is a bed of white wampum, which symbolizes the purity of the agreement. There are two rows of purple, and those rows have the spirit of your ancestors and mine. There are three beads of wampum separating the two rows and they symbolize peace, friendship, and respect. These two rows symbolize two paths or vessels, traveling down the same rivers

\footnotetext{
${ }^{9}$ John Borrows, "Wampum at Niagara: The Royal Proclamation, Canadian Legal History, and SelfGovernment," in Aboriginal and Treaty Rights in Canada: Essays on Law, Equality, and Respect for Difference, by Michael Asch (editor) (Vancouver: UBC Press, 1997), 161-163.

${ }^{10}$ With regards to the founding of the guswenta, while some historians agree that trade and commerce took place in the early 1600s, they date the Two-Row Wampum's creation as 1645 . However, Haudenosaunee oral tradition suggests that the agreement was solidified as early as 1613. See Ronald Wright, Stolen Continents: Conquest and Resistance in the Americas (Toronto: Penguin Group, 2003),

125-127. Also see, J.R. Miller, "'There is no end to relationship among the indians': Early Commercial Compacts," in Compact, Contract, Covenant: Aboriginal Treaty-Making in Canada, by J.R. Miller (Toronto: University of Toronto Press, 2009), 26.
} 
together. One, a birch bark canoe, will be for the Indian people, their laws, their customs and their ways. The other, a ship, will be for the white people and their laws, their customs and their ways. We shall each travel the river together, side by side, but in our own boat. Neither of us will try to steer the other's vessel. ${ }^{11}$

The guswenta provided the foundation for the relationship between the Dutch and the Haudenosaunee, and it defined acceptable behaviours and provided the political boundaries that neither party could violate. The Dutch accepted the wampum's terms, more than likely out of sheer necessity, since like other early commercial relationships, they, as European newcomers, depended on being introduced into the preexisting trade networks that the Haudenosaunee were part of. This turned out to be beneficial for both parties, since as this relationship developed, the Haudenosaunee were able to increase their influence in the region, solidifying themselves through trade and warfare as the middlemen between the Dutch and other Indigenous nations, while the Dutch were able to expand their economic interests in North America and in Europe.

In 1664, however, the British replaced the Dutch after a series of skirmishes between the two colonial powers throughout the 1600 s, and as a result, took on the roles and responsibilities that the Two-Row Wampum mandated, including the diplomatic protocols that were intrinsic to Haudenosaunee diplomacy. In this regard, I am referring to the process of "polishing the Silver Covenant Chain," which was a diplomatic and ceremonial process that flowed from, and reaffirmed the Two-Row Wampum's principles. Every year, British officials met Haudenosaunee leaders in front of Haudenosaunee villages to reaffirm their obligations to each other that were outlined in the guswenta, and solidified their partnership through rituals, gift giving, and speeches. ${ }^{12}$ As an oral society, Haudenosaunee leaders were elegant speakers, and demanded as much from their new

\footnotetext{
"Quote found in Turner, This is not a Peace Pipe, 48.

12 John Borrows, Canada's Indigenous Constitution (Toronto: University of Toronto Press, 2010), 76.
} 
partners, who had to quickly learn the importance of these annual protocols, since the Haudenosaunee saw speeches and the consistent giving of gifts as an extension of the other party's willingness to remain truthful to the Two-Row Wampum's spirit. ${ }^{13}$ In other words, in order to ensure that trade and military alliance was secure between the two parties, the British were expected to live up to the obligations that were embedded in the guswenta, which were centered around respect, and most importantly, non-interference.

This partnership continued into the $1700 \mathrm{~s}$, which was a century defined by constant warfare and conflict between expanding colonial empires. While Haudenosaunee diplomacy still operated during this century- sometimes to ensure their neutrality during the different colonial wars that defined this era- the constant conflict unavoidably placed increasing pressure on the integrity of their land base, as well as the land base of nearly every Indigenous nation. In light of this, after the Seven Years War between Britain and France that ended in 1763 , where the French lost and conceded its claims to New France and its other claimed territories, King George III of England declared the Royal Proclamation of $1763 .^{14}$

\subsection{The Royal Proclamation of 1763: Nation-to-Nation?}

The Royal Proclamation of 1763 addressed some of the problems that Britain faced after the Seven Years War, including demarking boundaries for white settlement, and more importantly, setting up strict rules for accessing and acquiring 'Indian land.' These boundaries and rules were set in place to reassure Indigenous nations that the British

\footnotetext{
${ }^{13}$ Wright, Stolen Continents, 126-127.

${ }^{14}$ J.R. Miller, "'And whereas it is just and reasonable...': The Royal Proclamation and the Upper Canadian Treaties," in Compact, Contract, Covenant: Aboriginal Treaty-Making in Canada, by J.R. Miller (Toronto: University of Toronto Press, 2009), 66.
} 
Crown was acting in their best interest by protecting their land, and thus their nationhood, from European encroachment by making it illegal to 'squat' on Indigenous land, as well as making it illegal for private parties to purchase land directly from Indigenous individuals. To acquire Indian land, the Proclamation stated that the Crown, through its public officials, were the only parties that could purchase land from an Indigenous group through treaty and compensation/annuities. An important provision the Proclamation also contained was its requirement for unanimity/consensus amongst the Indigenous group if a treaty that involved surrendering land was to take place. This was unproblematic for Indigenous groups, since it reflected the internal politic decision making of many Indigenous nations, who passed local, national, and confederacy level resolutions after reaching consensus. As I will explain later in this chapter, Indigenous communities would later use the Proclamation's unanimity/consensus provision to base their objection to the enfranchisement policies of the $19^{\text {th }}$ and $20^{\text {th }}$ centuries, since the land stipulations within these enfranchisement provisions ignored Indigenous protocol that was reaffirmed by the Royal Proclamation.

That said, while it has been suggested that the Crown's ability to create these rules was an extension of its new consolidated authority to deal with Indigenous people, which they gained by defeating the French, Anishinaabek legal scholar John Borrows suggests that the Royal Proclamation was in fact a continuation of its nation-to-nation relationship with Indigenous nations, and reflected the principles found in treaties such as the TwoRow Wampum. ${ }^{15}$ Borrows makes this claim for a number of reasons, one of the most important being that the British Crown was not entirely sure how Indigenous people

\footnotetext{
${ }^{15}$ Borrows, Wampum at Niagara, 155.
} 
would interpret their claim of sovereignty. ${ }^{16}$ This is because while the Royal Proclamation acknowledged the sovereignty of Indigenous nations as flowing from their use and occupancy of the land, it also elevated the political status of the British Crown in North America. According to Borrows, the Crown's new political status within the Indigenous/settler framework was reason for concern amongst Indigenous leaders, since they never agreed to cede their nationhood. ${ }^{17}$

In fact, even those nations that sided with the French during the Seven Years War viewed their sovereignty as still intact despite the fact that France lost to Britain. ${ }^{18}$ This perspective is captured by the words of an Anishinaabe chief who sided with the French during the Seven Years War, who stated, "Englishman, although you have conquered the French you have not yet conquered us! We are not your slaves. These lakes, these woods and mountains, were left to us by our ancestors. They are our inheritance, and we will part with them to none." 19 In short, while the Royal Proclamation addressed some of Britain's most pressing needs in North America, it still left loose ends that needed to be addressed regarding their relationship with Indigenous people.

These issues and concerns led to a meeting at Niagara in the summer of 1764 , where over 2,000 leaders from at least two-dozen Indigenous nations, including delegates from the Haudenosaunee, the Anishinaabe, and the Mi'kmaq, met with Sir William Johnston and other Crown officials. ${ }^{20}$ The meeting followed the same diplomatic protocols that most of the parties were accustomed to, including speeches, gift giving, and other ceremonial processes. These actions reflect the idea that British officials

\footnotetext{
${ }^{16}$ Borrows, Wampum at Niagara, 160-161.

${ }^{17}$ Borrows, Wampum at Niagara, 163.

${ }^{18}$ Miller, "The Royal Proclamation and the Upper Canadian Treaties," 72-73.

${ }^{19}$ Borrows, Wampum at Niagara, 157.

${ }^{20}$ Borrows, Wampum at Niagara, 162-163.
} 
viewed Indigenous leaders and the nations they represented as sovereign equals, since they met with these leaders according to Indigenous protocols, within a nation-to-nation framework.

Once assembled, each party was able to speak about their understanding of the Proclamation, and most Indigenous leaders discussed the idea that the document was a continuation of their centuries old agreement of respect and non-interference, much in line with the principles of the guswenta. ${ }^{21}$ Some Indigenous leaders even produced the Two-Row Wampum, and articulated their understanding of the Proclamation in light of this wampum belt, pointing out that they never ceded their sovereignty and that they expected the Crown to acknowledge their nationhood. Sir William Johnston acknowledged these claims, saying that the Royal Proclamation was indeed an agreement of non-interference, even for those nations who sided with the French. ${ }^{22}$ To prove this, each Indigenous nation that attended the meeting at Niagara, including those who sided with the French, were brought into the Silver Covenant Chain's jurisdiction, thus solidifying their nationhood and reaffirming the Crown's willingness to have a relationship based on peace and friendship, within a nation-to-nation framework. ${ }^{23}$

In line with Indigenous protocol, the agreement that was reached at Niagara in 1764 was recorded in wampum belts and oral traditions, and its principles were followed over the next few decades, most notably with the continuation of the Crown's obligation to provide Indigenous nations with gifts, particularly throughout the War of 1812 . It is arguable that the nation-to-nation framework that was codified in the Royal Proclamation, and then reaffirmed with the Treaty at Niagara, even extended to the numbered treaties

\footnotetext{
${ }^{21}$ Borrows, Wampum at Niagara, 163.

${ }_{22}^{22}$ Borrows, Wampum at Niagara, 164.

${ }^{23}$ Miller, "The Royal Proclamation and the Upper Canadian Treaties," 72.
} 
that were negotiated between the newly formed Canadian state and the Indigenous nations who occupied the western prairies towards the end of the nineteenth century, which corresponds with how elders and Indigenous leaders from that region interpreted and understood the treaty process. That is, the numbered treaties, often touted as an extension of Canada's willingness to exert its sovereignty over this region and subjugate the Indigenous people living on the land, should actually be viewed as a series of agreements/treaties of respect and non-interference.

The Royal Commission on Aboriginal Peoples echoes this perspective towards the numbered treaties, and states that Indigenous nations who entered into the treaty process, viewed the treaties as an agreement to share the land and work together to maintain peaceful relations, much in line with the principles of the Two-Row Wampum. ${ }^{24}$ Borrows suggests that interpreting the numbered treaties through this lens is not only historically accurate, but also morally accurate, since relying on dominant discourses and legal positivist lenses to interpret treaties only reaffirms the Crown's exclusive sovereignty by ignoring Indigenous voices. ${ }^{25}$

With that said, while I agree with the interpretation that John Borrows provides with regards to the Royal Proclamation and the Treaty of Niagara, his argument's legal and moral significance is overshadowed by the shift that occurred in the early to mid nineteenth century, when the colonial government began to initiate its civilizing/assimilatory mandate, which included the attempt to introduce Eurocentric land tenure systems. This is not to suggest however, that I believe Borrows' understanding of the treaty relationship should be ignored. Instead, I think it is important to first

\footnotetext{
${ }^{24}$ Government of Canada, Royal Commission on Aboriginal Peoples, Royal Commission (Ottawa: Government of Canada, 1996), Vol.1, Part 1, Ch. 6, "Displacement and Assimilation," 133.

${ }^{25}$ Borrows, Wampum at Niagara, 171-172.
} 
understand how the nation-to-nation relationship eroded before we begin to utilize these principles in order to reset the relationship back to a more equitable and just foundation. Only once this history is understood and appreciated can we move towards providing decolonizing solutions in light of the treaty relationship, since this history provides context, and more importantly, demonstrates what does not work.

\section{PART 2: 'Defining and Civilizing the Indian Problem'}

\subsection{Shifting Imperial Relations: Early Nineteenth Century Paradigms of Assimilation}

It is understood that the Crown started to move away from the nation-to-nation framework in the early nineteenth century. Generally speaking, this occurred after the War of 1812 , when terms of peace were negotiated between the British Crown and the United States. This peace allowed the Crown to focus its attention to expanding its territorial land base in the northern half of North America, which proved both at the time, and in hindsight, to be detrimental to Indigenous nationhood, since this peace initiated a new phase in the relationship between the Crown and Indigenous people. No longer seen as militarily useful, the relationship became much more coercive and oppressive, where the Crown's agents and their religious partners began to initiate a civilizing agenda that discarded not only the nation-to-nation framework, but condemned the traditions and epistemologies of Indigenous people. History however, is not this simple or linear, and the end of the War of 1812 was not the only factor that initiated the shift towards civilizing.

Historian J.R. Miller points out how a number of other factors led to this shift over the span of a few decades, starting with Loyalist immigration from the United States 
after the Revolutionary War, which placed pressure on the colonial government to open up land for settlement. Miller also draws attention to the merger of the Montreal-based North West Company with the Hudson's Bay Company in 1821, which practically eliminated the need for Indigenous commercial partners in the eastern Canadian fur trade. ${ }^{26}$ The most significant event that contributed to the erosion of the nation-to-nation framework occurred in 1830, when responsibility for Indian Affairs was transferred from British military officials to colonial/civilian bureaucrats. ${ }^{27}$ This change in political authority gave individuals who had no understanding of the nation-to-nation relationship, nor any experience of interacting with Indigenous nations as equals, the ability to create policies that directly impacted Indigenous people.

These civilian officials were imbued with a sense of cultural superiority, and they felt it was their duty, alongside the church, to help Indigenous people adopt a sedentary and agricultural lifestyle to replace their 'savage' subsistence lifestyles, and broader land based economies. ${ }^{28}$ This was the 'civilizing' phase of the shifting relationship, and it was defined by informal attempts to introduce agriculture, as well as a Christian education to Indigenous people in order to create self-sufficient communities. This phase lasted from the late 1820 s until 1857 , when the newly formed province of Canada took a more aggressive approach towards civilizing Indians with the Gradual Civilization Act $1857 .{ }^{29}$

With regards to the civilizing phase of early Indian policy, the first step was to create permanent reserves in present-day southern Ontario in the early 1830 s. These

\footnotetext{
${ }^{26}$ J.R. Miller, "From Alliance to Irrelevance," in Skyscrapers Hide the Heavens: A History of Indian-White Relations in Canada 3rd Ed., by J.R. Miller (Toronto: University of Toronto Press, 2000), 103.

${ }^{27}$ Miller, "From Alliance to Irrelevance," 118.

${ }^{28}$ Canada, Royal Commission on Aboriginal Peoples, Vol. 1, Part 1, Ch. 6, "Displacement and Assimilation," 134.

${ }^{29}$ Canada, Royal Commission on Aboriginal Peoples, Vol. 1, Part 2, Ch. 9, "The Indian Act," 243.
} 
reserves were created for Anishinaabe bands, since some reserves had already been created for the Haudenosaunee in both Upper Canada (Six Nations) and Lower Canada (Kahnawake) in the eighteenth century by either purchasing the land from another Indigenous group, as was the case with Six Nations, or by way of French royal decree, as was the case with Kahnawake. ${ }^{30}$ Regardless of how the reserve came into existence, missionaries became responsible for implementing the civilizing agenda, since they had been living amongst Indigenous groups for over fifty years, if not longer, and had learned their languages and customs. ${ }^{31}$

The civilizing agenda was multifaceted, with emphasis placed on education, agriculture, and individual land tenure, where their implementation and adoption were assumed to be in the best interest of Indigenous people. This was because most church and colonial officials thought a European-based education combined with the agricultural methods of dominant society, along with their individualistic attitudes towards land ownership, could replace traditional Indigenous lifestyles, which would help their communities become self sufficient and better able to cope with the changing world around them. ${ }^{32}$ At first, many Indigenous communities were willing to adopt education, since their leaders recognized that an education, especially the ability to read, write, and perform basic math, would provide them with security against being cheated by fur traders, land speculators, or Crown negotiators. ${ }^{33}$ Moreover, their capacity to have a say in how education curriculums would be developed made their decision easier. As a result,

\footnotetext{
${ }^{30}$ Canada, Royal Commission on Aboriginal Peoples, Vol. 1, Part 1, Ch. 6, “Displacement and Assimilation," 136.

${ }^{31}$ Miller, "Reserves, Residential Schools, and the Threat of Assimilation," in Skyscrapers Hide the Heavens: A History of Indian-White Relations in Canada, by J.R. Miller (Toronto: University of Toronto Press, 2000), 126.

${ }^{32}$ Miller, "Reserves, Residential Schools, and the Threat of Assimilation," 126.

${ }^{33}$ Miller, "Reserves, Residential Schools, and the Threat of Assimilation," 130.
} 
schools were built in a few communities, often at the request of the community's leadership, and often built using the band's monies.

Likewise, some communities also welcomed agriculture, since they saw the potential in farming as a means to complement their subsistence lifestyle, since they did not intend to completely abandon their lifestyle out on the land. ${ }^{34}$ Nonetheless, this became a relatively moot point, since by the end of the 1830 s, most communities that adopted agriculture started to become frustrated with this experiment altogether. This frustration can be pinned on the difficulties associated with adopting a sedentary lifestyle in a short time frame, as well as the interference that missionaries imparted in the lives of the community's religious men, which went beyond the task they were given to provide agricultural instructions. Given this frustration, and the fact these communities retained the self-governing ability to make decisions about their future, many communities simply abandoned farming. ${ }^{35}$ Interestingly, the failures of the agricultural program extended to the educational program as well, but not necessarily for the same reasons.

Instead, the failure of these early community-based schools was a result of how their educational curriculums shifted towards religious indoctrination, which conflicted with how parents and leaders wanted the schools to function. Most parents wanted their children to receive a simple education for the reasons mentioned above regarding the ability to protect their communities from unscrupulous traders and government officials, and were therefore displeased to find out that missionary teachers were going beyond that calling. As a result, parents started to keep their children from going to the schools, which caused Indian Affairs officials to conclude that the civilizing agenda was ineffective, and

\footnotetext{
${ }^{34}$ Miller, "Reserves, Residential Schools, and the Threat of Assimilation," 126.

${ }^{35}$ Miller, "Reserves, Residential Schools, and the Threat of Assimilation," 129.
} 
that they needed to reconsider their approach. However, this was not the only factor that led officials to reconsider their approach to civilizing Indians, since they also considered how every Indigenous community rejected an important feature of the civilizing project: individual land tenure.

This represents the first time that Crown and church officials attempted to introduce individual land tenure to Indigenous communities, and the fact this proposal was firmly rejected at the outset is an important historical fact to highlight, since the basis for their rejection reflects the reasons why private property/individual land tenure should be rejected by Indigenous people in general: they were afraid, and rightly so, that it would undermine their preexisting land holding patterns (lead to assimilation), and erode their land base (lead to dispossession). Community members wanted to retain their traditional land holding patterns, and were simply not interested in the individualistic values that were embedded in this type of land holding system, since it ran contrary to their cultural values.

This decision, as well as the relative failure of the agricultural and educational programs, led to frustration within the office of those responsible for Indian Affairs, who saw the civilizing program as an increasingly expensive project. However, its failure had a graver, yet unintended consequence as well, in that it caused Sir Francis Bond Head, who was the Lieutenant-Governor of Upper Canada in the late 1830s, to conclude that Indians in general were unable to adapt to British/Canadian society, and should thus live out their remaining days in isolation. ${ }^{36}$ This protectionist attitude was based on his experience visiting Ojibwa communities in the mid 1830s that were already part of the civilizing program. From Bond Head's perspective, the Ojibwa were woefully unable to

${ }^{36}$ Canada, Royal Commission on Aboriginal Peoples, Vol. 1, Part 2, Ch.9, "The Indian Act," 245. 
adopt the instructions they were receiving, which caused him to conclude that Indian policy should shift towards moving Indians away from settler society and abandon the civilizing project altogether. This resulted in a series of land surrender treaties in presentday southern Ontario throughout the late 1830-1840s, where the Anishinaabe in the region were convinced by Bond Head and other Crown officials to move to Manitoulin Island and live out their remaining days in isolation until they faded away as a people. ${ }^{37}$ However, this policy was short lived, since it faced opposition from the religious community, as well as from the Anishinaabe themselves, who opposed having to surrender more of their land. ${ }^{38}$

While Bond Head's policies were short lived, the legislators of both Upper and Lower Canada utilized his protectionist mentality, and in 1839-1840, declared that reserves were Crown land. ${ }^{39}$ This made it illegal for non-Indians to squat, or even trespass onto a reserve without permission from the appropriate government authority, which reaffirmed the Royal Proclamation's provision that land could not be sold to a private third-party. Despite this reaffirmation, these decisions signaled that colonial officials were still interested in pursuing the civilizing agenda by protecting their land bases.

\subsection{The Bagot Commission: Towards an Integrated Indian Policy}

When the 1840s arrived, it was assumed by Indian Affairs officials that the program of the 1830 s had failed to achieve its objectives. Therefore, after failing to see any progress

\footnotetext{
${ }^{37}$ Miller, "Reserves, Residential Schools, and the Threat of Assimilation," 131-132.

${ }^{38}$ Miller, "Reserves, Residential Schools, and the Threat of Assimilation," 132.

${ }^{39}$ Canada, Royal Commission on Aboriginal Peoples, Vol. 1, Part 2, Ch. 9, "The Indian Act," 245.
} 
being made in terms of civilizing, in 1842, frustrated Indian Affairs officials asked Sir Charles Bagot to conduct an inquiry into the living conditions of reserves, and make recommendations for the future. ${ }^{40}$

In 1844, at the end of his two-year inquiry, Sir Charles Bagot came to a variety of conclusions, the most important one being that he found that Indians were only 'halfcivilized. ${ }^{, 41}$ This finding provided the basis for his recommendations, but rather than placing the blame for the lack of civilizing progress entirely on Indigenous people, he found that there was a serious lack of oversight in terms of administering land transactions and band funds, as well as stopping illegal squatting and timber cutting. ${ }^{42}$ In other words, rather than questioning the program in its entirety, particularly its rationale, the lack of civilizing progress was reduced to an administrative problem within the Indian Affairs department. To address the perceived problem, Bagot made a series of recommendations that would influence Indian policy for years to come.

Administratively, he recommended that responsibility for Indian Affairs be consolidated into one centralized authority so that Indian policy would be relatively uniform. This would help keep track of the Indian population, since he also recommended that a census be taken in Upper Canada, and eventually Lower Canada, where only names that appeared on the band lists would receive treaty annuities. ${ }^{43}$ In order to address more specific problems like the issue of illegal timber cutting and nonIndian squatters, Bagot recommended that timber licenses be instituted for reserves, and that reserve boundaries be surveyed, publically announced, and that all transactions be

\footnotetext{
${ }^{40}$ Canada, Royal Commission on Aboriginal Peoples, Vol. 1, Part 2, Ch. 9, "The Indian Act," 245-246.

${ }^{41}$ John S. Milloy, A National Crime: The Canadian Government and the Residential School System I879 to 1986 (Winnipeg: The University of Manitoba Press, 1999), 12.

${ }^{42}$ Canada, Royal Commission on Aboriginal Peoples, Vol. 1, Part 2, Ch. 9, "The Indian Act," 246.

${ }^{43}$ Canada, Royal Commission on Aboriginal Peoples, Vol. 1, Part 2, Ch. 9, "The Indian Act," 247.
} 
recorded and considered binding. However, he did not want the reserve system to disappear immediately, and instead recommended that gradual steps be taken to allow Indigenous communities to civilize at their own pace. ${ }^{44}$

In this regard, Bagot reemphasized the importance of education and schools, but thought that since the current system was not very effective, he recommended that industrial schools be built off of the reserve so that the parents would not be able to influence their children, and derail their progress. The forerunner to the more recent residential school system, the industrial school was meant to introduce Indian children to Christianity, farming techniques, and a basic education, which were considered to be the cornerstones of European civilization. ${ }^{45}$ The educational curricula were to be highly gendered, where the boys would receive farming and mechanical training, while the girls were to receive training in domestic arts. ${ }^{46}$

These recommendations were meant to complement Bagot's other primary recommendation, which was the introduction of individual land allotments. According to Commissioner Bagot, while the 1839-1840 Acts of the Upper and Lower Canadian legislators served to protect the land base of Indigenous nations, he actually considered this to be an impediment to their eventual citizenship, since he felt Indians were being sheltered from various aspects of Euro-Canadian life, such as voting (since only landowners could vote), property taxation, and liability to have their land seized in event of non-payment of debt. ${ }^{47}$ In light of this, Bagot recommended that Indians be given the chance to buy and sell plots of land amongst themselves in order to get used to the idea of

\footnotetext{
${ }^{44}$ Olive Dickason, Canada's First Nations: A History of Founding Peoples from Earliest Times (Don Mills: Oxford University Press, 2002), 227.

${ }^{45}$ Milloy, A National Crime, 13.

${ }^{46}$ Milloy, A National Crime, 13.

${ }^{47}$ Canada, Royal Commission on Aboriginal Peoples, Vol. 1, Part 2, Ch. 9, "The Indian Act," 247.
} 
interacting with each other and with the land like Europeans, so when the time came they would be able to fully integrate into the dominant society. ${ }^{48}$

While the Bagot Commission's educational provisions were generally welcomed, Indigenous communities challenged its assimilatory undertones. Like before, Indigenous leaders wanted the children in their communities to be educated, but they did not want it to be at the expense of their cultural identity. Likewise, Indigenous leaders also rejected the Commission's recommendation to subdivide their land base, since they did not want to move away from their traditional land holding patterns, which reflected their culture and identity. ${ }^{49}$

\subsection{Consolidating Aggressive Polices of Assimilation: Towards the 1876 Indian Act}

Many of the Bagot Commission's recommendations were implemented in the following years, including the establishment of industrial schools, as well as the protection of reserve lands from settler encroachment. This was accomplished in 1850 and 1851, when the provinces of Upper and Lower Canada passed pieces of legislation that made it an offence to encroach or settle on Indian land, which was more of a reactionary measure to address the illegal timber cutting that was occurring in the Temiskaming and Abitibi regions in present day Quebec. ${ }^{50}$ These pieces of legislation strengthened the earlier 1839 Act, and reaffirmed the Royal Proclamation of 1763 by making it illegal to directly deal with Indigenous nations with regards to land. These pieces of legislation also introduced the idea that property could not be seized for payment of debt, as well as the idea that

\footnotetext{
${ }^{48}$ Canada, Royal Commission on Aboriginal Peoples, Vol. 1, Part 2, Ch. 9, "The Indian Act," 247.

${ }^{49}$ Miller, "Reserves, Residential Schools, and the Threat of Assimilation," 133.

${ }^{50}$ Dickason, Canada's First Nations, 228.
} 
reserves were exempt from taxation. ${ }^{51}$ While individual land allotments were left out of these pieces of legislation due to the resistance it faced, "Indianness" was defined for the first time in Lower Canada, which initiated a system of classification that would be refined over the decades with little to no regard for how Indigenous people actually formed their identity.

In the eyes of the Indian Affairs department, defining who was an Indian was a necessity, considering the amount of land that was involved, as well as the accompanying issue of treaty annuities..$^{52}$ In 1851 , the legislator of Lower Canada defined an Indian as someone of Indian blood who belonged to a particular tribe or band; any person who married into a body of Indians and lived amongst them, and any children of such a union; a person living amongst such a body of Indians, and either one of their parents was an Indian; lastly, all persons who were adopted into the tribe as an infant and lived among them. ${ }^{53}$

A year later, this definition was considered to be too broad, and was soon reconfigured to exclude non-Indians living amongst the tribe, as well as non-Indian men who were married to native women; these same Indian women who married non-Indian men retained their Indianness, but it was not passed down to their children. Interestingly, when the reverse was true and a non-Indian woman married an Indian man, she gained Indian status, as did their children, thus establishing the idea that identity and privileges flowed through the paternal line, which would be retained in the Indian Act for years to come. $^{54}$

\footnotetext{
${ }^{51}$ Canada, Royal Commission on Aboriginal Peoples, Vol. 1, Part 2, Ch. 9, "The Indian Act," 248.

${ }^{52}$ Dickason, Canada's First Nations, 228.

${ }^{53}$ Dickason, Canada's First Nations, 228-229.

${ }^{54}$ Dickason, Canada's First Nations, 229.
} 
While these pieces of legislation were a direct result of the Bagot Commission's recommendations, they had little impact on civilizing rates. Progress in this regard was still slow, and failed to meet the department's expectations, which firmly believed their efforts over the past few decades would have at least created self-sufficient communities that could compete with, if not fully integrate into dominant society. To say the least, Indian Affairs officials were troubled with the program's slow progress, and like many times before, initiated a number of inquiries to look into this perceived problem. An important inquiry was the Pennefeather Commission, which was established in 1858 to look into ways that the civilizing agenda could be better achieved. At its core, this commission recommended that a more aggressive policy be established; one that promoted assimilation rather than civilization, and one that promoted individual land tenure arrangements to replace traditional land holding patterns. ${ }^{55}$ Interestingly, John A. Macdonald, who would later become the first Prime Minister of Canada, was already implementing this commission's recommendations a year before when he helped enact, An Act to Encourage the Gradual Civilization of the Indian Tribes of the Canadas, also known as the Gradual Civilization Act $1857 .^{56}$

\section{PART 3: 'Eliminating the Indian Problem'}

\subsection{Enfranchisement Before the Indian Act: 1857-1876}

After a frustrating civilizing experience, the province of Canada passed the Gradual Civilization Act in June 1857, which consolidated the laws and policies of the previous

\footnotetext{
${ }^{55}$ Canada, Royal Commission on Aboriginal Peoples, Vol. 1, Part 2, Ch. 9, "The Indian Act," 249.

${ }^{56}$ Dickason, Canada's First Nations, 229.
} 
few decades into one central document. This piece of legislation included educational provisions, as well as protective measures, such as freedom from taxation and protection against having land expropriated or dispossessed by private parties. Furthermore, like the 1851 Act of Lower Canada, it also defined Indianness, which reflected the continuous streamlining of Indian policy within the province of Canada, where access to rights and privileges now depended on an individual meeting the criteria set out in the Gradual Civilization Act. While this specific provision was problematic in its own right, since it ignored how Indigenous people formed and passed on their identities, it was actually not the most oppressive part of this piece of legislation. Instead, it was the new legal concept that the Gradual Civilization Act introduced that became its most known, and most despised feature: enfranchisement.

Enfranchisement was a legal mechanism that legally transformed an Indian into a citizen of the British Empire, which consequently meant being a landowner. While it sounds progressive, it was not a neutral or mundane process, since it was premised on the idea that the distinctive features of Indigenous identity and nationhood, which were represented by their Indian status, made Indians markedly different from members of the dominant society, and thus, unworthy of their respect. In order to gain the respect of dominant society, it was expected that would Indians shed their legal status as Indians, which meant renouncing their Indigenous identity, their ties to the community, their familial bonds, and their cultural traditions in order to gain colonial citizenship and individual property rights to a parcel of reserve land. ${ }^{57}$

Interestingly, colonial officials described enfranchisement as a sought after honour, or a gift, that Indians would be more than willing to embrace, and therefore made

${ }^{57}$ Canada, Royal Commission on Aboriginal Peoples, Vol. 1, Part 2, Ch. 9, "The Indian Act," 251. 
it a voluntary process. ${ }^{58}$ In fact, they were so confident that Indigenous communities would welcome enfranchisement that the Act made it an offence for an Indian to fraudulently present himself or herself as an enfranchised person. ${ }^{59}$ Those eligible for the franchise reflected colonial society's patriarchal power structure, and enfranchisement was only made available to any Indian male above the age of 21 , who could read and write in either English or French, was relatively educated, of good moral character, and free of debt as determined by a panel of non-native officials ${ }^{60}$ If an individual met these requirements and successfully enfranchised, they could gain up to 50 acres of reserve land and possess it as a life estate, but never in fee simple. ${ }^{61}$ The point in this was to ensure that the individual could gradually begin to understand how to be a British/Canadian landowner, and pass that knowledge onto his wife and children, who would also be enfranchised when he was.

This was an important feature of enfranchisement, as well as the larger goal of eliminating the reserve system, since when the man died, his children would inherit his property in fee simple. Once inherited, his children could exercise their private property rights as they saw fit. Interestingly, if the man died without heirs, the property would be transferred to his wife, who would hold the property in life estate until she died, which would then initiate the property being transferred to the Crown. ${ }^{62}$ This aspect of enfranchisement under the Gradual Civilization Act not only guaranteed that land ownership was a patriarchal institution, but it also ensured the reserve system would gradually fade away, since the Act did not contemplate giving the land back to the band.

\footnotetext{
${ }^{58}$ Dickason, Canada's First Nations, 229.

${ }^{59}$ Canada, Royal Commission on Aboriginal Peoples, Vol. 1, Part 2, Ch. 9, "The Indian Act," 249.

${ }^{60}$ Canada, Royal Commission on Aboriginal Peoples, Vol. 1, Part 2, Ch. 9, "The Indian Act," 249.

${ }^{61}$ Canada, Royal Commission on Aboriginal Peoples, Vol. 1, Part 2, Ch. 9, "The Indian Act," 249.

${ }^{62}$ Canada, Royal Commission on Aboriginal Peoples, Vol. 1, Part 2, Ch. 9, "The Indian Act," 249.
} 
In short, the Gradual Civilization Act's enfranchisement provision provided the colonial government with a mechanism that could legally eliminate the 'Indian problem' one plot of land at a time. ${ }^{63}$

While the colonial government was enthusiastic about this piece of legislation, the Gradual Civilization Act was hugely unsuccessful, since Indigenous communities rejected nearly every aspect of it, including its educational provisions. To Indigenous community members, the educational curriculum had assimilatory intentions, which conflicted with their desire for their children to receive a basic education. In response, parents demonstrated their disapproval by removing their children from the schools. ${ }^{64}$ However, communities displayed a lot more displeasure towards the Act's enfranchisement provision than they displayed against its educational provisions, since a lot more was at stake.

From the point of view of Indigenous communities, they felt enfranchisement, with its individual property rights stipulation, undermined the promises that were imbedded in the Royal Proclamation and the Treaty at Niagara. In this regard, Indigenous leaders argued that the Act contravened the Proclamation's guarantee that land could not be bought or sold without the band's approval. Moreover, they felt the unilateral nature of this provision undermined, and thus insulted, their self-governing ability to make political decisions, especially when it came to issues surrounding land surrenders. ${ }^{65}$ As one chief from Kahnawake suggested, the Gradual Civilization Act, with its ability to lead to the erosion of their land base, was designed to "break them to pieces."

\footnotetext{
${ }^{63}$ Dickason, Canada's First Nations, 229.

${ }^{64}$ Miller, "Reserves, Residential Schools, and the Threat of Assimilation," 143.

${ }^{65}$ Canada, Royal Commission on Aboriginal Peoples, Vol. 1, Part 2, Ch. 9, "The Indian Act," 250.

${ }^{66}$ Miller, "Reserves, Residential Schools, and the Threat of Assimilation," 141.
} 
concern, Indigenous leaders confronted the Crown's Indian Affairs officials, and requested that if the entire piece of legislation could not be rescinded, could the enfranchisement provision be repealed, since they were not interested in losing any more land. Indian Affairs officials denied this request, arrogantly stating to chiefs from Six Nations, "The Civilization Act is no grievance to you." ${ }^{, 67}$ This attitude did not sit well with Indigenous leaders, who initiated an outright assault against the Gradual Civilization Act.

One of the more common forms of resistance took place when Indigenous communities stopped their reserves from being surveyed, since the major reason for land surveying at this point in time was to delineate how land would be divided when a person enfranchised. ${ }^{68} \mathrm{~A}$ more aggressive form of resistance took place in Six Nations, where community members discouraged interested individuals from enfranchising due to the provision's capacity to erode their land base. In fact, when Elias Hill decided to enfranchise, who, I might add, was the only person to voluntarily enfranchise under this $A c t$, his request for his 50 acres of land was simply rejected by the Six Nations leadership. ${ }^{69}$

By the end of 1860 s, and Canada was established as a country, Indian Affairs conceded that the Gradual Civilization Act was failing to meet its objective with respect to enfranchisement. With only one person coming forward to voluntarily enfranchise, only to be undermined by the community's leadership, the department of Indian Affairs decided to reconsider their approach to Indian policy once again. But rather than revisiting the logic of enfranchisement as a policy goal, Indian Affairs officials decided to

\footnotetext{
${ }^{67}$ Miller, "Reserves, Residential Schools, and the Threat of Assimilation," 141.

${ }^{68}$ Canada, Royal Commission on Aboriginal Peoples, Vol. 1, Part 2, Ch. 9, "The Indian Act," 250.

${ }^{69}$ Miller, "Reserves, Residential Schools, and the Threat of Assimilation," 143.
} 
pursue it more vigorously with their new consolidated authority under section 91 subsection 24 of the British North America Act 1867. Through an act of the Canadian Parliament, the secretary of state became the Superintendent of Indian Affairs, and was granted exclusive jurisdiction over 'Indians and lands reserved for Indians. ${ }^{70}$

In 1869, the newly formed nation of Canada passed the Gradual Enfranchisement Act, which contained most of the same provisions as the previous Gradual Civilization Act 1857, including enfranchisement, but added new provisions that the government believed would help achieve civilization/assimilation more readily. While I will not discuss all of them in detail, since they were carried over into the Indian Act, I will highlight two key features.

The first provision that this $A c t$ contained that I feel needs to be mentioned is the introduction of the elected band council system. While government officials suggested that it was a privilege that was being bestowed onto Indigenous communities, since it was considered to be one of the finer aspects of 'civilization,' in actuality, it was meant to undermine the resistance that traditional leaders were displaying against enfranchisement. ${ }^{71}$ This is evident in the fact that the Gradual Enfranchisement Act required bands to get permission from the Superintendent of Indian Affairs for nearly every community decision. Even more harshly, this provision also gave the Superintendent the ability to depose leaders who were deemed 'unfit for office. ${ }^{72}$ Not surprisingly, being deemed 'unfit for office' was usually saved for instances where

\footnotetext{
${ }^{70}$ Canada, Royal Commission on Aboriginal Peoples, Vol. 1, Part 2, Ch. 9, "The Indian Act," 252.

${ }^{71}$ Canada, Royal Commission on Aboriginal Peoples, Vol. 1, Part 2, Ch. 9, "The Indian Act," 252.

${ }^{72}$ John Tobias, "Protection, Civilization, Assimilation: An Outline History of Canada's Indian Policy," in Sweet Promises: A Reader on Indian-White Relations in Canada, by J.R. Miller (editor) (Toronto: University of Toronto Press, 1991), 131.
} 
community leaders refused to cooperate with the department's civilizing/assimilatory agenda.

The introduction of the location ticket is the other aspect of the Gradual Enfranchisement Act that I believe needs to be mentioned, since its inclusion introduced an individualized system of land 'ownership' that not only contravened the numerous times Indians opposed similar proposals in the past, but it also generated a series of land tenure reforms that culminated with the 1951 amendments to the Indian Act. With regards to the location ticket under the 1869 Act, it was used by the department of Indian Affairs to further streamline the administration of Indian policy, since once a reserve was subdivided by land surveyors, the Gradual Enfranchisement Act forced individuals and/or their families to obtain a location ticket from the Superintendent of Indian Affairs in order to be considered in 'lawful possession' of the property, and more importantly, a member of the community. ${ }^{73}$ While this provision was objected to by Indigenous community leaders, it was becoming too late for dialogue at this point in time, since the government was not interested in hearing from the Indigenous population. ${ }^{74}$

\subsection{The Indian Act 1876}

The Indian Act was enacted in 1876 , consolidating many of the provisions from the 1857 and 1869 Acts, which were discussed earlier, into one piece of legislation. ${ }^{75}$ Although it was enacted to administer Indian policy, like the previous Acts that were just discussed, the Indian Act was an inherently paradoxical document, containing both protective provisions such as freedom from taxation and making personal property safe from seizure,

\footnotetext{
${ }^{73}$ Canada, Royal Commission on Aboriginal Peoples, Vol. 1, Part 2, Ch. 9, "The Indian Act," 254.

${ }^{74}$ Canada, Royal Commission on Aboriginal Peoples, Vol. 1, Part 2, Ch. 9, "The Indian Act," 254.

${ }^{75}$ Canada, Royal Commission on Aboriginal Peoples, Vol. 1, Part 2, Ch. 9, "The Indian Act," 255.
} 
while also containing provisions for coercive legal assimilation. ${ }^{76}$ This paradox was much more biased towards assimilation however, particularly during the early stages of the Indian Act, as can be discerned from the following excerpt from the department's 1876 annual report. Commenting on Indian policy's guiding philosophy, the report stated: “...the true interests of the aborigines and of the State alike require that every effort should be made to aid the Red man in lifting himself out of his condition of tutelage and dependence, and that is clearly our wisdom and our duty, through education and every other means, to prepare him for a higher civilization by encouraging him to assume the privileges and responsibilities of full citizenship." ${ }^{, 77}$ In other words, Indians and their lands were only to be were protected so that one day they would be ready for citizenship, which is an important issue to remember, particularly in light of the First Nations Property Ownership Act, since it seems the developers of the FNPOA believe Indians are now ready for citizenship (land ownership). But with respect to the 1876 Indian Act, in order to prepare Indians for citizenship, the department of Indian Affairs had two approaches: gradual assimilation through Euro-Canadian indoctrination, and immediate assimilation through compulsory and voluntary enfranchisement.

\subsection{Band Councils}

With regards gradual assimilation, the ability to indoctrinate Indians with Euro-Canadian values was accomplished when the Superintendent of Indian Affairs was given complete control over Indigenous communities, using the Indian Act to implement the department's assimilatory agenda. First imposed on reserves that already existed in

\footnotetext{
${ }^{76}$ Canada, Royal Commission on Aboriginal Peoples, Vol. 1, Part 2, Ch. 9, "The Indian Act," 255. See also, Tobias, "Protection, Civilization, Assimilation," 132.

${ }^{77}$ Canada, Royal Commission on Aboriginal Peoples, Vol. 1, Part 2, Ch. 9, "The Indian Act," 255.
} 
eastern Canada, the Indian Act introduced various Eurocentric concepts and institutions that were meant to gradually transform community members into assimilable individuals who would be ready for citizenship. Besides education, one of the main institutions the Indian Act incorporated from the previous 1869 Act was the municipal style band council. Modified from a three-year elected term under the Enfranchisement Act, to a two-year term under the Indian Act, the band council was meant to introduce Indians to EuroCanadian political values and concepts, such as voting within an electoral system, so that when they entered dominant society, they would be able to participate in Canada's political life.

Band councils however, had a much more insidious mandate besides indoctrination, in that they were designed to displace and undermine the authority of traditional leaders and traditional governance systems. ${ }^{78}$ Learning from the previous few decades, the department realized that traditional leaders were an impediment in the way of assimilation, and the department figured the band council was an effective tool to undermine their authority. Despite initial optimism towards its effectiveness however, band councils were actually ineffective at first, and in most instances, rejected by communities, since the 1876 Indian Act made them a voluntary measure. ${ }^{79}$ In fact, even when Indian Affairs officials started to promise leaders that their communities would receive more power and jurisdiction over local matters if they adopted a band council government structure, communities still rejected this proposal.

This is because Indigenous leaders recognized that not only did it conflict with their political values, but they also recognized that once they adopted a band council

\footnotetext{
${ }^{78}$ Canada, Royal Commission on Aboriginal Peoples, Vol. 1, Part 2, Ch. 9, "The Indian Act," 257.

${ }^{79}$ Tobias, "Protection, Civilization, Assimilation," 132.
} 
government, their self-governing authority would be undermined since the Indian Act gave complete discretionary power to the Superintendent of Indian Affairs, who could veto nearly every decision they made. ${ }^{80}$ Nonetheless, despite the opposition this provision faced, band councils would eventually be imposed in many communities due to an 1880 amendment to the Indian Act, which gave the Superintendent the authority to impose band councils on communities that he thought were ready for this type of governance system. $^{81}$

In western Canada, things took a slightly different course of action. With respect to the area where the numbered treaties were signed, reserves in this region were created as a treaty right, and as such, they were meant to exist forever, much like other treaty rights. In order to practically and legally implement this specific right to reserve land, reserves were transformed into Crown land- like reserves in eastern Canada- and were thus protected from alienation and dispossession. ${ }^{82}$ Despite twenty-first century attitudes towards this protective measure, where it is often described as unneeded paternalism, signatories did not have a problem with this aspect of the Indian Act, since they were looking out for their future generations. In fact, they believed this protective measure reflected the meaning of the Royal Proclamation of 1763, which, as I discussed earlier, made their lands inalienable.

With that said, while most communities were immediately brought under the Indian Act's jurisdiction after band members settled onto the reserve, communities in this region were not introduced to the band council right away. Instead, Indian Affairs

\footnotetext{
${ }^{80}$ Canada, Royal Commission on Aboriginal Peoples, Vol. 1, Part 2, Ch. 9, "The Indian Act," 257.

${ }^{81}$ Tobias, "Protection, Civilization, Assimilation," 133.

${ }^{82}$ Canada, Royal Commission on Aboriginal Peoples, Vol. 1, Part 1, Ch. 6, "Displacement and Assimilation," 149.
} 
officials often held informal elections in order to gradually engender local Indians with Euro-Canadian political values, while focusing most of their attention on 'civilizing' them using the Indian Act as a means to administer this agenda. Much like the civilizing agenda of the 1830-1850s that was implemented in eastern Canada, Indians in western Canada received education- albeit in industrial and residential schools- and Christianization. They also received agricultural instructions, as well as tools for farming, which were included in the treaties. However, unlike the 1830-1850s civilizing agenda, they- along with every other Indigenous nation in Canada- faced religious persecution, when the Indian Act was amended in 1884-5 to prohibit spiritual practices and ceremonies in hopes that it would accelerate assimilation. ${ }^{83} \mathrm{~A}$ truly oppressive and damaging provision, this section of the Indian Act forced Indians to gradually lose this aspect of their culture, or they were forced to take it underground. Nonetheless, this provision was finally repealed in 1951 along with other oppressive provisions, although its long-term effects continue to be felt now, as many communities are struggling to maintain their languages and traditional ceremonies.

\subsection{The Location Ticket}

Having discussed the imposition of band councils, and touching upon the prohibition of Indigenous spirituality, which were both implemented to undermine, displace, and eradicate Indigenous cultures, another important feature of the Indian Act that had assimilatory intentions was the location ticket. While individuals or families could still

\footnotetext{
${ }^{83}$ J.R. Miller, "The Policy of the Bible and the Plough," in Skyscrapers Hide the Heavens: A History of Indian-White Relations in Canada, by J.R. Miller (Toronto: University of Toronto Press, 2000), 260-261.
} 
legally occupy reserve land using customary land holdings (which will be described in chapter 3), the department encouraged Indians to adopt the location ticket.

Like the Gradual Enfranchisement Act, the purpose of the Indian Act's location ticket provision was to make the administration of Indian policy more efficient by stipulating that in order to have better on-reserve property rights, a band member and their family needed to obtain a location ticket from the band council. While this approach was designed to streamline administration, its larger mission was to engender individualism in the location ticket holder, which Indian Affairs officials thought would eventually turn into 'pride in land-ownership,' thus breaking down the communal nature of their communities. According to department officials, the communal nature of their communities was an extension of their traditional land tenure arrangements, which they thought were not only backwards, but were also thought to engender idleness, since it was assumed Indians would not want to 'improve' the land under their traditional land tenure arrangements. ${ }^{84}$

I should point out that this assumption was quickly disproved by reserves in western Canada in the early twentieth century, which despite living under the Indian Act's oppressive jurisdiction and its severe restrictions on the selling of agricultural produce, were in fact very efficient farmers that used their 'collective' mentality and their customary land holdings to successfully participate in large-scale agricultural projects. Unfortunately, this success was short lived after local Indian Agents, pressured by neighbouring non-native farmers, discouraged this kind of agriculture, since they did not want Indians to become anything more than "peasant farmers." 85 This latter fact

\footnotetext{
${ }^{84}$ Canada, Royal Commission on Aboriginal Peoples, Vol. 1, Part 2, Ch. 9, “The Indian Act," 257.

${ }^{85}$ Miller, "The Policy of the Bible and the Plough," 271.
} 
demonstrates that the push towards individualized land allotments was an ideological agenda to eradicate any remnants of Indigenousness, including their attitude towards land use.

\subsection{Voluntary and Compulsory Enfranchisement}

While the previous discussion highlighted the Indian Act's gradual assimilatory provisions (band councils and the location ticket), the following discussion is going to discuss the issue of enfranchisement, or more accurately described as legal assimilation. Enfranchisement constitutes the second approach the department took towards eliminating the reserve system, and can be defined by a desire to achieve the immediate eradication of Indigenous people as individuals and communities.

Introduced in 1857 under the Gradual Civilization Act, enfranchisement was carried over into the 1869 Gradual Enfranchisement Act, and finally into the 1876 Indian Act, only to be completely repealed in 1985 . During its inclusion in the Indian Act from 1876 to 1985 , enfranchisement went through a series of changes, adapting and evolving to the resistance that Indigenous communities displayed against it. For instance, when the Indian Act was first enacted, it contained the familiar voluntary enfranchisement provision, a new compulsory provision, and a new reserve-wide provision that allowed entire communities to enfranchise.

With respect to individual voluntary enfranchisement, it operated much like it did under the pieces of legislation from 1857 and 1869, where individuals could approach the department, or their local Indian Agent, choose to voluntarily enfranchise themselves, and after a three-year probationary period gain individual property rights to a section of reserve land. However, that is where the similarity ends. In a rare instance of gender 
equality, the 1876 Indian Act, which denied native woman the ability to vote in band elections, allowed both men and unmarried women over the age of 21 to voluntarily enfranchise ${ }^{86}$ The Indian Act's other key distinction exists in the process that took place after the three-year probationary period. While all three successive pieces of legislation contained this probationary clause, under the 1876 Indian Act, after the man or woman proved they were ready for citizenship, they were given documents that granted them fee simple rights to a plot of land, making it alienable right away. However, this was quickly amended so that alienation could only take place with the department's approval. ${ }^{87}$ That being said, even with these changes, it is peculiar that the Indian Act included this voluntary provision in the first place considering how vehemently it was challenged and resisted in previous pieces of legislation, although it does explain why the department introduced compulsory enfranchisement.

With regards to this involuntary provision, the Indian Act stated that any Indian who received a university education, or became a Christian minister, lawyer, or doctor, would be automatically and immediately enfranchised; there would be no probationary period. ${ }^{88}$ The logic behind this provision, which the immediacy of the provision reflects, was that when an Indian gained an education, it symbolized that they had embraced EuroCanadian values, and there was therefore no point in having them 'prove' their eagerness to gain citizenship. Not surprisingly, this did not reflect the desires of any Indians who were involuntarily enfranchised-or were likely to be enfranchised - under this provision, since not only did they lose their Indian status, but also, they were not allowed to return back to their communities. This would be addressed when the compulsory

\footnotetext{
${ }^{86}$ Canada, Royal Commission on Aboriginal Peoples, Vol. 1, Part 2, Ch. 9, "The Indian Act," 264.

${ }^{87}$ Canada, Royal Commission on Aboriginal Peoples, Vol. 1, Part 2, Ch. 9, "The Indian Act," 257.

${ }^{88}$ Canada, Royal Commission on Aboriginal Peoples, Vol. 1, Part 2, Ch. 9, "The Indian Act," 257.
} 
enfranchisement provision was repealed in 1880 , allowing those with a university education to retain their Indian status and live on the reserve. However, in a seeming attempt to give these same individuals the ability to enfranchise, an amendment in 1884 removed the right of band councils to refuse to consent to having a portion of land removed from the reserve land base. ${ }^{89}$

Compulsory enfranchisement would reappear in the Indian Act in 1918, when the Act was amended to allow the Superintendent to enfranchise Indians living off of the reserve. This amendment targeted native women who were usually widowed, having moved off of the reserve with their husbands. To the great pleasure of the department, this amendment achieved immediate results, since prior to 1918 , only 102 Indians had enfranchised, while between 1918-1920 alone, an astounding 258 people were enfranchised largely due to this single amendment. ${ }^{90}$

In 1920, the department of Indian Affairs added another element to its compulsory enfranchisement provision, where it stated that a board of examiners, appointed by the Superintendent, could determine if an Indian man or woman over the age of 21 was ready for citizenship. ${ }^{91}$ If found to be 'prepared' for the responsibility, the board would report back to the Superintendent, who would then recommend to the governor in council that the person was fit for enfranchisement, which would then initiate the process where the individual would be enfranchised two years after the finding, and would receive a plot of land in fee simple. ${ }^{92}$ Since it was a compulsory provision, nowhere in this process did the individual have a say regarding their perspective on

\footnotetext{
${ }^{89}$ Canada, Royal Commission on Aboriginal Peoples, Vol. 1, Part 2, Ch. 9, "The Indian Act," 264.

${ }^{90}$ Canada, Royal Commission on Aboriginal Peoples, Vol. 1, Part 2, Ch. 9, "The Indian Act," 264.

91 Tobias, "Protection, Civilization, Assimilation," 137.

${ }^{92}$ Canada, Royal Commission on Aboriginal Peoples, Vol. 1, Part 2, Ch. 9, "The Indian Act," 264.
} 
enfranchisement, although their resistance to this measure was undoubtedly captured in the community wide effort against it. Due to this measure's potential to further erode the reserve land base, Indigenous leaders challenged this aspect of the Indian Act, which led to this provision being repealed two years later in $1922 .{ }^{93}$ However, whatever gain this repeal might have symbolized was short lived, since not only did the Indian Act still permit voluntary enfranchisement, but the department also reintroduced compulsory enfranchisement back into the Act in 1933, where if an individual met a series of predetermined criteria, they would have been enfranchised against their will. This remained until 1951.

Interestingly, another compulsory provision was maintained in the Act even after the 1951 amendments. It was maintained until 1961, and gave the Superintendent the authority to appoint a board of examiners to determine if a man was ready for enfranchisement. ${ }^{94}$ But these were not the only enfranchisement provisions that were maintained after the 1951 amendments. Instead, community wide enfranchisement provisions were maintained in the Indian Act until 1985.

\subsection{Community Wide Enfranchisement}

Community wide enfranchisement was introduced in the first 1876 Indian Act, and allowed entire bands to voluntarily enfranchise. ${ }^{95}$ Considering the historic resistance that enfranchisement faced in general, one might wonder why this provision was included, let alone think that an entire band would willingly abandon their collective Indian status. However, that is exactly what happened.

\footnotetext{
${ }^{93}$ Miller, "The Policy of the Bible and the Plough," 281.

${ }^{94}$ Canada, Royal Commission on Aboriginal Peoples, Vol. 1, Part 2, Ch. 9, "The Indian Act," 290.

${ }^{95}$ Canada, Royal Commission on Aboriginal Peoples, Vol. 1, Part 2, Ch. 9, "The Indian Act," 264.
} 
In 1881, after centuries of displacement, conflict, disease, and warfare, the entire Anderdon Wyandotte (Wendat) band of southern Ontario enfranchised. ${ }^{96}$ Prior to this, the band had moved from their traditional lands in the late 1600 s to escape the Haudenosaunee, moving close to present day Windsor, Ontario. Once there, the people lived on two fairly large reserves, which were eventually surrendered to the Crown in the early nineteenth century, leaving only a small acreage, which happened to be the land that was allotted in 1881 when the band enfranchised. Community members received documents of private possession to their parcels of land in 1884, which represented their official enfranchisement. Not surprisingly, the Anderdon band's decision to enfranchise provided the department with a sense of purpose, and motivated them to continue with their agenda, which explains why this provision was maintained until 1985.

It would be utilized only one more time in 1958, when the Michel band of Alberta was enfranchised, gaining private property rights to their individual plots of land, as well as the proceeds from the sale of their remaining lands. ${ }^{97}$ Like the Anderdon band, the department of Indian Affairs described the Michel band as 'progressive,' portraying them as a model community that other reserves should emulate, which provides insight into the department's attitude towards Indian policy. Quite simply, the department's decision to describe the Michel band, as well as the Anderdon band, as progressive was based on the simple fact that they appeared to have embraced Euro-Canadian values, but more importantly, because they ceased to be financial burdens.

\footnotetext{
${ }^{96}$ Canada, Royal Commission on Aboriginal Peoples, Vol. 1, Part 2, Ch. 9, "The Indian Act," 264.

${ }^{97}$ Canada, Royal Commission on Aboriginal Peoples, Vol. 1, Part 2, Ch. 9, "The Indian Act," 287.
} 


\section{Chapter 3- The White Paper and the FNPOA}

The previous discussion left off describing how community wide enfranchisement provisions within the Indian Act led to the elimination of the protected status of two First Nations reserves, the first time in the 1880s, and then again in 1958. In the collective mind of the department of Indian Affairs, this reaffirmed their faith in Indian policy's assimilatory mandate, which motivated the department to continue down the same path as previous decades. However, the influence these two instances had on the development of the White Paper is difficult to determine, considering a multitude of factors contributed to its introduction in 1969. With that said, I would argue that these factors are just as important to understanding the White Paper as understanding the document itself, which is why this section of my thesis will describe this historical context.

\section{PART 1: 'The 1969 White Paper'}

\subsection{Towards the White Paper}

The road towards the White Paper started in the years following the Second World War, when native veterans returned to their communities and initiated a series of political upheavals, which led to various legislative amendments in the years to come. However, the political chaos the veterans stirred up was unfortunately motivated by the marginalization they experienced after the war.

While their families and communities welcomed them when they returned home, native veterans often faced discrimination and unfair treatment when trying to access 
benefits under the Veterans Land Act (VLA). This piece of legislation was supposed to help returning veterans get back on their feet by providing them with options for loans, as well as providing them with land for farming and/or other economic pursuits. With respect to native veterans however, their Indian status often barred them from accessing the same benefits as their non-native counterparts. This was largely due to the $V L A$ 's loan provisions, which required the veteran be able to own the land the $V L A$ provided as a form of collateral. But as I discussed in the previous chapter, the Indian Act prohibited Indians from owning reserve land, which in turn restricted them from accessing certain benefits under this $A c t$.

Unfair treatment also occurred due to the uncontrolled discretion the $V L A$ gave Indian agents. Quite simply, the Veterans Land Act gave the Indian agent the ultimate authority to determine an Indian veteran's suitability for other types of federal loans under this $A c t$, which led to questionable and unfair situations where Indian agents could, and often did, deny veterans other benefits they were entitled to. As a result, many veterans were forced to accept lesser benefits under the $V L A$, move off of the reserve to receive loans on par with their non-Indian counterparts, or in some instances, enfranchise themselves. ${ }^{98}$ This kind of unfair treatment undoubtedly inspired the native community to voice their frustrations beginning in the late 1940 s and early 1950s, since these communities, spearheaded by native veterans, were frustrated about their institutionalized poverty and marginalization.

Within a few years after the war's end, national, provincial, and regional political organizations were established, with native veterans often occupying a pivotal role in

\footnotetext{
${ }^{98}$ For more details, see, Canada, Royal Commission on Aboriginal Peoples, Vol. 1, Part 2, Ch. 12, "Veterans," 551-556.
} 
their development and subsequent activism. For instance, the Union of Ontario Indians, the Indian Association of Manitoba, and the North American Indian Brotherhood were all established in 1946, which gave their spokespersons a platform to voice their concerns during government hearings, such as the 1946-1947 Joint Senate and House of Commons Committee, which was tasked with reviewing Indian policy. ${ }^{99}$ The Indian Association of Manitoba played a particularly crucial role in this hearing, where their spokesperson, Tom Prince, himself a World War Two veteran, discussed his discontent with the situation his constituency faced after the war. However, he argued for 'equality on par with other Canadians,' something his constituency did not necessarily agree with, who instead wanted proper treaty implementation, or at least to have a dialogue with the government regarding this issue. ${ }^{100}$

Treaty implementation was a common theme that other Indigenous people/parties also brought up at the 1946-47 Parliamentary hearings, as was the issue of revising the Indian Act so that communities could have more control over their lives without having to receive ministerial approval, assimilate, or give up their Indian status. Recent grievances were also brought up at this hearing, including the frustrating experience that veterans faced after the war. ${ }^{101}$ Finally, these organizations stated their desire to repatriate reserve land that had been leased during the war for farming, or for other purposes such as artillery practice, since large plots of land were leased to the military, often without the band's consent. ${ }^{102}$

\footnotetext{
${ }^{99}$ Canada, Royal Commission on Aboriginal Peoples, Vol. 1, Part 2, Ch. 12, "Veterans," 557.

${ }^{100}$ Canada, Royal Commission on Aboriginal Peoples, Vol. 1, Part 2, Ch. 12, "Veterans," 558.

${ }^{101}$ Canada, Royal Commission on Aboriginal Peoples, Vol. 1, Part 2, Ch. 12, "Veterans," 558-559.

${ }^{102}$ Canada, Royal Commission on Aboriginal Peoples, Vol. 1, Part 2, Ch. 12, "Veterans," 560.
} 
While the 1946-47 hearings gave the Indigenous community an opportunity to speak, the hearing's recommendations, which were released in 1948 , did not truly reflect their demands. Coming from the point of view that Indians were 'almost' assimilated, the committee recommended that the Indian Act be revised to limit the department's ability to interfere in a community's decision making authority, as well as recommending that the Indian Act's more coercive features be repealed so that Indians could assimilate on their own without being pressured by the department of Indian Affairs. ${ }^{103}$ In other words, the committee recommended that the Indian Act be amended to give Indians the space they needed to assimilate on their own, and at their own pace.

In light of these recommendations, the Indian Act was amended a few years later in 1951, when various provisions were repealed, such as compulsory enfranchisement (see Ch. 2 for a more thorough discussion on which enfranchisement provisions were still maintained after 1951 amendments), the prohibition against making a legal claim against the government, the prohibition against practicing Indigenous spirituality, and the ban on alcohol consumption. ${ }^{104}$ However, the 1951 Indian Act maintained its underlying assimilatory mandate, which is evident based on the introduction of new land-holding provisions that were meant to continue the gradual indoctrination of Indians with western land holding concepts. These were meant to replace the location ticket system, and included the 'certificate of possession,' as well as new leasing provisions.

Getting back to the issue at hand, despite the 1946-1947 hearings and the 1951 Indian Act amendments, a series of inquiries and commissions were established once again throughout the 1950 s and 1960s, acting as measures to determine how Indian

\footnotetext{
${ }^{103}$ J.R. Miller, "The Beginnings of Political Organizations," in Skyscrapers Hide the Heavens: A History of Indian-White Relations in Canada, by J.R. Miller (Toronto: University of Toronto Press, 2000), 326.

${ }^{104}$ Miller, "The Beginning of Political Organization," 326.
} 
policy was progressing. An important commission was established in 1959, which was tasked with the responsibility of looking into the future of Indian policy. Like the 19461947 hearings, native peoples were asked to participate, and like before, they took the opportunity to discuss their concerns about the unbearable socio-economic conditions their communities were experiencing. They also placed a renewed emphasis on treaty implementation and addressing land claims, as well as asking the department to stop interfering in their day-to-day decision-making. ${ }^{105}$ Despite this input, the committee's recommendations did not reflect their demands, and like the 1946-1947 recommendations, promoted assimilation. Instead of using the word 'assimilation' however, the department changed its rhetoric and suggested that the purpose of Indian policy in the post-1951 era was to help Indians prepare for their eventual citizenship and integration into Canadian society, ${ }^{106}$ which I should add, was foreshadowed when the department was relocated and turned into a branch of the department of Citizenship and Immigration in 1947.

Returning to the 1959-1960 hearings, they did not produce as many policy changes as the previous 1940s Parliamentary hearings, considering only two major changes resulted from its recommendations. The first was the elimination of compulsory enfranchisement for Indian men and entire communities, which was repealed from the Indian Act in 1961. The second was the creation of a claims commission in 1961-1962, although its establishment was more of a result of a sudden influx of land claims following the 1951 Indian Act amendments, where the provision that prohibited an Indian band from making a legal claim against the government was repealed. This claims commission adjudicated on matters related to treaty rights, reserve lands (unfair leases

\footnotetext{
${ }^{105}$ Canada, Royal Commission on Aboriginal Peoples, Vol. 1, Part 2, Ch. 9, "The Indian Act," 290.

${ }^{106}$ Canada, Royal Commission on Aboriginal Peoples, Vol. 1, Part 2, Ch. 9, "The Indian Act," 290.
} 
and surrenders), and band monies, although it was abandoned shortly after due to a newly elected Liberal government, which disbanded the claims commission in $1964 .{ }^{107}$ It would only be reestablished in the mid 1970s, after the Supreme Court of Canada reaffirmed the existence of Aboriginal title in its Calder decision, which initiated a series of comprehensive land claims.

Not surprisingly, the department of Indian Affairs was not fond of the claims commission when it was first established in 1961-62, since they thought it was an unnecessary expense, not to mention a major distraction, since they figured Indians would turn their focus on addressing historic grievances instead of focusing on their future citizenship. ${ }^{108}$ This mentality reflected the department's general attitude towards Indian policy, which genuinely believed they were a few stages/policy amendments away from fulfilling their assimilatory mission: the elimination of Indians as a social and legal fact. However, realizing that Indians were still not fully assimilated, and that most of the mechanisms for legal enfranchisement had been repealed from the Indian Act, the department of Indian Affairs asked Dr. Harry Hawthorn to look into reserve conditions, as well as the prospect of complete assimilation.

After an extensive investigation, where Indigenous community members were asked to participate, the 1966-67 Hawthorn Report reaffirmed the department's suspicion that Indians had not assimilated. However, much to the department's displeasure, the Hawthorn Report suggested that they should abandon its assimilatory agenda and instead start engaging Indians as 'citizens plus.' By 'citizens plus,' the Report referred to the idea

\footnotetext{
${ }^{107}$ John F. Leslie, "The Policy Agenda of Native Peoples from WW2 to the 1969 White Paper," in Aboriginal Policy Research: Setting the Agenda for Change (Vol. I), by Jerry P. White et al. (editors) (Toronto: Thompson Education Publishing , 2004), 18-19.

${ }^{108}$ Leslie, "The Policy Agenda of Native Peoples," 20.
} 
that Indians should be treated like Canadian citizens, but receive more rights-based benefits based on their Indian status, such as continued tax exemption. ${ }^{109}$ According to the Report, this type of treatment reflected the nation-to-nation agreements that were negotiated in the previous decades/centuries, where Indigenous nations allowed EuroCanadians to use their land in exchange for certain rights and privileges. ${ }^{110}$

Although not a perfect reflection of how Indigenous people understood the treaty relationship, this perspective was brought up in 1968, when department of Indian Affairs officials initiated another consultation process, going across the country to ask Indigenous communities about their perspectives on Indian policy. While it might have seemed redundant to have established yet another consultation process so quickly after the Hawthorn Report, this particular consultation process was actually quite different from previous hearings and inquiries, since not only did it have a broader set of issues to investigate, but federal officials went out of their way to interview as many First Nations communities as possible. Not surprisingly, this caused the native community to believe their historic claims were going to be addressed, and that progress was being made towards reestablishing a more just relationship. In fact, even the department of Indian Affairs seemed willing to cooperate with Indigenous people, promising after the 19681969 consultation process to establish more hearings in the future. ${ }^{111}$ Unfortunately, any optimism for a renewed relationship, let alone future hearings, would be shattered a few months later when the federal government released the "Statement of the Government of Canada on Indian Policy," also known as the 1969 White Paper. ${ }^{112}$

\footnotetext{
${ }^{109}$ Leslie, "The Policy Agenda of Native Peoples," 22.

${ }^{110}$ Canada, Royal Commission on Aboriginal Peoples, Vol. 1, Part 2, Ch. 9, "The Indian Act," 291.

III Miller, "The Beginnings of Political Organization," 331.

112 Leslie, "The Policy Agenda of Native Peoples," 22.
} 


\subsection{The White Paper}

Considering the countless inquiries, commissions, and consultation processes that were established in the previous decades, it is no surprise that Indigenous people were dismayed and completely taken by surprise when the White Paper was released. For one thing, the White Paper did not reflect any of the things that Indians had asked for in the previous hearings, nor did it reflect the Hawthorn Report's recommendation to treat Indians as 'citizens plus,' itself a watered down interpretation of the treaty relationship. Instead, the White Paper approached the issue of reforming Indian policy from within a framework defined by liberal values.

According to Indigenous scholar Dale Turner, liberalism is a theory of political justice, where an individual's freedom and integrity are the most important things to account for when developing a legal and moral framework to guide interpersonal and governmental/individual relationships. To protect the individual's freedom and integrity within a liberal framework, similar treatment (equality) must be emphasized, while differential treatment (inequality) must be limited, if not completely eliminated. With respect to the role of the state in this process, it must measure equality between individuals, and when conflict occurs between an individual and a group, it is the state's fundamental duty to ensure the interest of the individual always prevails. ${ }^{113}$ This is accomplished by guaranteeing individuals are treated the same, which is itself accomplished through political processes, law, the state's constitution, and the court system, all of which are charged with preserving basic human and civil rights, which are instrumental to any decent human existence.

\footnotetext{
${ }^{113}$ Turner, This is not a Peace Pipe, 13.
} 
That said, while this brief description undoubtedly missed the nuances within liberal thought, my point was not to describe this system of political thought in finite detail, but rather describe its basic tenets in order to judge the White Paper against its embedded values.

To start, the White Paper was premised on the point of view that differential treatment is fundamentally wrong and incompatible with a liberal democracy. According to the White Paper, whether the differential treatment that Indians experienced was worse, similar, or slightly better, "what matters is that it has been different." 114 Interestingly, the White Paper did not appreciate the notion that differential treatment was based on treaty promises and other historic agreements that were negotiated in the past between sovereign and political equals, which makes its characterization of certain rights as a form of 'differential treatment' historically and legally inaccurate. Nevertheless, the White Paper bunched any form of special rights into this category, which it then erroneously described as the source of Indigenous poverty. ${ }^{115}$ While there was an element of truth to this statement regarding poverty, particularly in light of the Indian Act's oppressive economic features (not including its prohibition against owning reserve land), the White Paper did not make the distinction between treaty rights and provisions within the Indian Act. Instead, the White Paper homogenized these differences, and stated that continuing down the road of 'different status' would be detrimental to the well being of Indian people, as well as the unity of the country. ${ }^{116}$

Based on these findings, the White Paper suggested the best way forward for Indians was to give them unfettered access to the economy and Canada's political

\footnotetext{
${ }^{114}$ Canada, Statement on Indian Policy 1969, 4.

${ }^{115}$ Canada, Statement on Indian Policy 1969, 4.

${ }^{116}$ Canada, Statement on Indian Policy 1969, 5.
} 
systems by removing institutional barriers, thus giving Indians the ability to integrate and fulfill their roles as Canadian citizens. To help Indians integrate into Canadian society, the White Paper recommended- since it was not an affirmed policy directive, but rather a reflection of the government's intentions- the Indian Act be repealed, Aboriginal rights be abolished, which meant the treaties be dissolved, reserve lands be turned into private property (emphasis my own), and responsibility for social services be transferred to the provinces so that Indians could receive services through the same administrative channels as every other Canadian citizen. ${ }^{117}$ In other words, the federal government was trying to offload its expensive fiduciary duty to the provinces, while simultaneously accomplishing its long term goal of assimilating Indians, which, according to previous hearings, was 'almost accomplished' despite the Hawthorn Report's claim to the contrary.

With regards to the White Paper's private property provision, it stated that since Indians were almost assimilated, "Control of Indian lands should be transferred to the Indian people." ${ }^{118}$ This was of course part of the government's assimilatory agenda to turn Indians into full-fledged Canadian citizens, which, according to the White Paper, meant land-ownership. Like previous attempts to introduce private property to Indians, the White Paper did not shy away from the Eurocentric relationship between landownership and citizenship. Instead, the White Paper embraced this relationship, stating that Canadian citizenship implied municipal/provincial/federal taxation, as well as the associated risks and responsibilities that come with fee simple land ownership. According to the White Paper, "The Government believes that full ownership implies many things.

${ }_{117}$ Canada, Statement on Indian Policy 1969, 7-8.
${ }^{118}$ Canada, Statement on Indian Policy 1969, 21. 
It carries with it the free choice of use, of retention or of disposition." ${ }^{119}$ While I would argue it is not surprising that the White Paper included private property as one of its main recommendations, especially in light of the numerous times the federal government tried to introduce it in the past (see Ch. 2), what is surprising, or at least illuminating, is how its authors tried to justify its inclusion.

Besides this provision's ability to fit within Prime Minister Pierre Trudeau's ideological outlook (especially his vision of creating a 'just society'), since citizenship within a liberal democracy means the ability to own land, ${ }^{120}$ the authors of the White Paper also tried to suggest that Indians had in fact asked for private property rights during the 1968-1969 consultation meetings. ${ }^{121}$ While it was completely incorrect and dishonest for the White Paper to claim Indigenous people had asked for private property rights during those meetings, I should note that Indigenous spokespersons did in fact ask for more control over their traditional territories, as well as more control over the land on their reserves. Unfortunately, the department of Indian Affairs ignored their claim for increased jurisdiction over the traditional territories, and manipulated their other comment regarding reserve land so it fit within the White Paper's overall assimilatory agenda.

Simply put, the authors of the White Paper took the Indigenous community's desire for 'more control over their land,' and manipulated it to suggest that Indians had asked for private property rights. The White Paper went further however, and added that Indians were frustrated with the Indian Act's land provisions, which I should note was true, but not to the extent that they wanted to make their lands alienable in the real estate

\footnotetext{
${ }^{119}$ Canada, Statement on Indian Policy 1969, 22.

${ }^{120}$ Turner, This is not a Peace Pipe, 22.

${ }^{121}$ Canada, Statement on Indian Policy 1969, 21.
} 
market. Nevertheless, the authors of the White Paper acted as if Indians had asked for private property rights, and drew attention to the problems Indians experienced trying to access loans and mortgages, as well as pointing out how the cumbersome administrative process involved in on-reserve economic development stymied any chance for success, since all land related decisions required departmental approval. According to the White Paper, departmental approval made on-reserve business and economic development slow and uneconomical, since it added 'unnecessary' bureaucratic red tape. ${ }^{122}$ In light of this, the White Paper suggested that private property was the most appropriate solution, since property owners have the right to make decisions regarding their land without government approval, as well as being able to access mortgages and loans.

However, as I mentioned earlier, this justification was based on a falsehood, since it did not reflect what Indigenous people had asked for during the previous hearings. Instead, it was a way to justify the government's predetermined agenda, which was already in motion before the White Paper was even introduced in 1969. According to historian J.R. Miller, in the months leading up to the White Paper's release, internal documents between the department of Indian Affairs and the Prime Minister's Office reveal how bureaucrats within the department were frustrated and at their wits end; they wanted out of the expensive Indian business. ${ }^{123}$ This suggests that it took the countless hearings, inquiries, and consultation processes for the department to realize that regardless of their determination, Indians would not willingly go away.

Frustrated with this reality, since it meant continually funding an expanding bureaucracy, and an 'Indian problem' that was not improving, key players within the

\footnotetext{
${ }^{122}$ Canada, Statement on Indian Policy 1969, 21.

${ }^{123}$ Miller, "The Beginnings of Political Organization," 334.
} 
department of Indian Affairs started to formulate ways to end the government's fiduciary duty, by turning Indians into citizens with no special rights or privileges. Since enfranchisement did not work in the past, the White Paper became the perfect solution to eliminate the expensive 'Indian problem' once and for all.

\subsection{The Backlash}

Considering the White Paper's genocidal implications, which were compounded by its unilateral features, the backlash against the White Paper was not only immediate, but also vehement. Similar to the native activism that occurred in the years following the Second World War, activism following the White Paper's introduction was multifaceted, where national, provincial, and regional organizations spoke out against its indifference for the issues that were brought up at previous hearings, as well as for its complete disregard for Indigenous rights. Harold Cardinal, a young Cree lawyer at the time, was able to capture all of these frustrated voices in his book, The Unjust Society, which was released just months after the White Paper was introduced.

Like the native political organizations, Cardinal strongly opposed the White Paper for its technical components/recommendation, as well as for its ideological underpinnings. For instance, Cardinal questioned Prime Minister Trudeau's quest to create a 'just society' when it meant obliterating the legal mechanisms that protected Aboriginal and treaty rights, which consequently meant obliterating the people themselves. Cardinal accurately called this an attempt at 'cultural genocide,' later suggesting in his book that Canadian Indian policy had not moved away from its assimilatory origins. In fact, when describing the department of Indian Affairs' approach to Indian policy, Cardinal stated the 
department still believed and formed its policies according to the idea that, "The only good Indian is a non-Indian."124

Examining Cardinal's statements in a contemporary context, it becomes clear that his arguments against the White Paper fall into the analytical framework that Dale Turner provides in his book, This is not a Peace Pipe: Towards a Critical Indigenous Philosophy. In this regard, Cardinal pointed out how the White Paper failed to address the legacy of colonialism, which is evident in the White Paper's misunderstanding of the root causes of Indigenous poverty. According to Cardinal and Turner, Indigenous poverty is a symptom of a much larger socio-political problem, where the historic marginalization and oppression Indigenous peoples experienced, on top of the state's inability to properly implement the treaties, has led to their current state of economic dependency, which is a problem that is not mentioned in the White Paper.

According to Turner and Cardinal, the fact these issues are not mentioned in the White Paper is itself a reflection of the historic marginalization that Indigenous people faced, since their voices have either been rejected, ignored, or as the preceding discussion illustrated, distorted to reaffirm the state's agenda. ${ }^{125}$ In light of this, both Turner and Cardinal both argue that Indigenous voices must be included in the development of a theory of Aboriginal rights, although Cardinal took a slightly different approach, and stated that Indians must be engaged so documents like the White Paper can be avoided in the future. In light of this backlash, the White Paper was retracted a few months later as a basis for Indian policy, but as the upcoming discussion will illustrate, its underlying

\footnotetext{
${ }^{124}$ Harold Cardinal, The Unjust Society (Seattle: University of Washington Press, 1999), 1.

${ }^{125}$ Found in Turner, This is not a Peace Pipe, 30-31.
} 
intentions have not been completely abandoned, especially with respect to introducing private property rights.

\section{PART 2: On and Off Reserve Property Rights}

Before analyzing the First Nations Property Ownership Act, I need to take some time to discuss the land tenure regimes in Canada that exist both on reserve, as well as in dominant society. While this discussion will be legalistic and quite extensive, it will provide my forthcoming analysis of the FNPOA with the appropriate context, and more importantly, it will provide further insight into the issues the authors of Beyond the Indian Act: Restoring Aboriginal Property Rights discussed and addressed in the pages of their book. In this regard, I will highlight the legal features of on-reserve property rights, including their qualities that make them either conducive, or an impediment to on-reserve economic development, at least according to the authors of the aforementioned book.

\subsection{Land Tenure On First Nations Reserves: An Overview}

In most of Canada, especially in regions where treaties were negotiated, reserves were created when an Indigenous nation's Aboriginal title was extinguished in exchange for certain identifiable treaty rights, one of them being reserve land. As a result, the common law in Canada recognizes that the Crown holds underlying/reversionary title to a reserve for the benefit of the band. ${ }^{126}$ Because of this arrangement, legally speaking, reserve land is inalienable, although it can still be expropriated or surrendered, but only to the Crown, which is a reflection of the historic Royal Proclamation of 1763.

\footnotetext{
${ }^{126}$ Jack Woodward, Native Law (Scarborough: Carswell Thomson Professional Publishing, 2007), 275.
} 
This common law principle also has bearing on a band member's ability to own land on a reserve, since this principle also prohibits individual Indians from owning fee simple rights to a portion of reserve land, since use and occupation of land is a collective right that is to be enjoyed by the entire band. This point is clearly articulated in section 20(1) of the Indian Act, which states, "No Indian is lawfully in possession of land in a reserve unless, with the approval of the Minister, possession of the land has been allotted to him by the council of the band." While I should note this means that a band member cannot own reserve land, I should also point out that Indians can possess other legal interests to occupy and use reserve land, which are set out in the Indian Act.

\subsection{Customary Land Holdings}

Interestingly, the most prevalent form of property right on reserves are customary/traditional land holdings, which are actually not defined within the Indian Act. Instead, this property right is an extension of the band council's ability to use reserve land for the benefit of the community's band members, including for residence or economic development. ${ }^{127}$ They are a common feature among western Canadian reserves, where customary land holdings emerged as reserves were created by treaty. In many cases, families simply continued to occupy the same land they had for generations, or after they settled on to a reserve, the band divided the land amongst the people according to their cultural values. Either way, these transactions were recorded according to oral tradition, which acted to solidify a family's claim to a parcel of land. However, as a band's membership grew, and land became less plentiful, more formal recording mechanisms were created to deal with potential conflict.

${ }^{127}$ Flanagan, Alcantara, and Le Dressay, Beyond the Indian Act, 74. 
To address this issue, some band councils started to pass band council resolutions to formally announce a plot of land belonged to a certain band member/family, which was followed by the land being surveyed. ${ }^{128}$ After this, the transaction would be finalized when it was recorded in a community land registry. This 'legitimized' this form of land tenure, particularly in the eyes of the department of Indian Affairs, since there was formal documentation- as opposed to oral tradition- to prove a band member's right to occupy the land. However, while the department might have been pleased with how this reflected an internalization of western values in terms of indefeasible/exclusive land ownership, the department lacked, and still lacks to this day, any authority in these kinds of local matters, since discretion over customary land holdings remains with the band. ${ }^{129}$ The department of Indian Affairs is only brought into the process when a band member wants to lease their land, which requires Ministerial approval. In fact, leasing reserve lands in general requires departmental approval, regardless of what kind of property right the band member possesses.

That being said, customary land holdings do have weaknesses, considering these kinds of land holdings do not afford the band member with much security, or legal protection, since a simple band council resolution could dispossess a family from their plot of land in order to meet a community's collective goals. Moreover, since customary land holdings lack a legislative basis, courts are reluctant to enforce them against such actions. ${ }^{130}$ Nonetheless, despite their lack of security, most bands still defend customary land holdings as being able to best reflect their cultural attitudes towards land and land

\footnotetext{
${ }^{128}$ Flanagan, Alcantara, and Le Dressay, Beyond the Indian Act, 78.

${ }^{129}$ Christopher Alcantara and Tom Flanagan, "Individual Property Rights on Canadian Indian Reserves," Fraser Institute, accessed on October 25, 2012, http://www.fraserinstitute.org/researchnews/display.aspx?id=13114, 5 .

${ }^{130}$ Alcantara and Flanagan, "Individual Property Rights on Canadian Indian Reserves" 6.
} 
use, since not only are land transactions still recorded through oral tradition, but there is also a communal/cultural aspect to them that other property rights under the Indian Act severely diminish. ${ }^{131}$ Moreover, since the department does not have any jurisdiction in dealing with, or legitimizing customary land rights, this form of land tenure gives a community a certain degree of autonomy compared to communities that are subdivided by leases and/or certificates of possession.

\subsection{Permits, Designations, and Individual Leases}

Having discussed customary land holdings, leases constitute another form of property right that exists on a reserve, although unlike the previous land regime, they are defined under the Indian Act, having been reformulated and reintroduced during the 1951 amendments. Generally speaking, leases can be granted on a band's communal lands, or on an individual band member's allotted land, using their certificate of possession, or in some instances, their customary land holding once they possess a band council resolution.

With regards to band-administered leases, the first is the short-term lease, or more accurately defined as a 'permit,' which allows the Minister to grant any person (native or non-native) the ability to reside on, occupy, or use reserve land for no longer than one year. For short-term leases, band council support is not needed, while Ministerial approval is crucial, since short-term leases are unenforceable if they are acted upon without the department's approval. ${ }^{132}$ Interestingly, band council approval is also unneeded when renewing a short-term lease. Instead, band council approval is only

\footnotetext{
${ }^{131}$ Alcantara and Flanagan, "Individual Property Rights on Canadian Indian Reserves" 5.

${ }^{132}$ Woodward, Native Law, 263.
} 
needed in instances where the permit is going to last for more than one year. ${ }^{133}$ This effectively means that a band council has virtually no control over short-term leases that are less than one year in duration, and limited control over short-term leases that extend over a year (since the band council must approve), even though in both instances, they are a source of revenue for the band via renter's fees.

The second band-administered lease is the long-term lease, also known as a 'designation,' which, like its title suggests, is for extended periods of time. Considering the duration of these kinds of leases are usually very long (in some cases, 99 years), the Indian Act requires eligible community members vote on the issue of designating land for a long-term lease. Only if approved by a majority of the voters, the band council can forward its consent to the Minister, who then designates the land for leasing. ${ }^{134}$ Once reserve land has been designated for a long-term lease, it can be occupied and utilized by either native or non-native people for residential purposes, and/or commercial purposes.

An example of a successful designation can be found near the Cowichan reserve in British Columbia, where the band council and certain members who held certificates of possession were able to come to an agreement, where their plots of land would be leased over an extended period of time to construct retail stores in Duncan, British Columbia, a neighbouring, non-Indian community. According to the agreement, the certificate holders would receive $90 \%$ of the leasing revenue, while the band would receive the remaining $10 \% .{ }^{135}$ This was obviously a favourable outcome for all of the parties involved,

\footnotetext{
${ }^{133}$ Alcantara and Flanagan, "Individual Property Rights on Canadian Indian Reserves," 11.

${ }^{134}$ I should note the process involved in designating land for a long-term lease has been amended recently, whereby the voting threshold for designating land for long-term leases has been significantly reduced. Due to the recent amendments, only a majority of those who show up to a scheduled vote is needed to designate land for a long-term lease. Flanagan, Alcantara, and Le Dressay, Beyond the Indian Act, 100.

${ }^{135}$ Alcantara and Flanagan, "Individual Property Rights on Canadian Indian Reserves," 12.
} 
particularly the band, since the land was being leased, not surrendered, which meant it remained inalienable, and would eventually revert back to the band, who can decide in the future, in cooperation with the certificate holders, as to whether it will go down the same path and designate the land again. ${ }^{136}$

The third kind of lease that is outlined in the Indian Act is the individual lease, which is available to band members who possess a certificate of possession, although there are ways in which a band member can lease their customarily held land when they possess a band council resolution. With regards to band members who possess certificates of possession, the Indian Act provides them with two provisions that detail how they can lease their land. First, when a member's land is being unused and they are indifferent to how it is developed, the certificate holder can lease their land with the approval of both the band council and the Minister of Indian Affairs under section 58(1)(b) of the Indian Act. ${ }^{137}$ Section 58(3) of the Act provides certificate holders with another option, which allows a certificate holder to directly approach the Minister to approve their application to lease their land, effectively bypassing the need to secure the band council's consent. ${ }^{138}$

In other words, both kinds of individual leases allow a band member to pursue their economic interests using their certificate of possession, although limitations are placed on what kinds of things they can do. For instance, a band member's development plans need to respect the band's zoning by-laws, which do not necessarily act as vetoes on development, but rather create standards to guide the kind of development that can

\footnotetext{
${ }^{136}$ Alcantara and Flanagan, "Individual Property Rights on Canadian Indian Reserves," 12.

${ }^{137}$ Alcantara and Flanagan, "Individual Property Rights on Canadian Indian Reserves," 14.

${ }^{138}$ Alcantara and Flanagan, "Individual Property Rights on Canadian Indian Reserves," 14.
} 
take place. ${ }^{139}$ In situations where a band member wants to develop their land against the band's wishes, the Minister can respond by ensuring that the band council's concerns are addressed before making the decision to grant a lease. While the band's concerns will not override individual leases every time, the Minister is required, due to his/her fiduciary duty, to consider the duration of the lease, as well as how the tenant's use might impact the land, before making a decision to grant a lease. ${ }^{140}$ Therefore, even lands that are held with a certificate of possession are subject to a community's standards and environmental values.

\subsection{Certificates of Possession}

The last kind of property right that exists on a reserve is the certificate of possession, which is found in section 20(2) of the Indian Act, which states that a band member who is in lawful possession of land on a reserve can receive a certificate of possession from the Minister of Indian Affairs after being approved by the band council. Certificates of possession were introduced in 1951, although as I mentioned before, they were specifically designed to further indoctrinate Indians with Euro-Canadian attitudes towards land ownership. This is evident based on its legal characteristics, which are very similar to fee simple ownership, although there are major differences separating these two forms of land tenure.

With regard to their similarities, like fee simple ownership, a holder of a certificate of possession is in legal possession of a section of land, meaning other members of the band, and even the band council itself, loses its "collective right to

\footnotetext{
${ }^{139}$ Woodward, Native Law, 286.

${ }^{140}$ Woodward, Native Law, 286.
} 
occupy that portion of the reserve, and... the individual may occupy and develop the s. 20 lands (allotted lands) without interference by the band council or other band members." ${ }^{\prime 41}$ Due to this principle, a holder of a certificate of possession may hold their interest in the land indefinitely, and can pass it along to an heir, as long as the heir is also a band member. A certificate holder can also sub-divide, transfer, or sell their land, but again, it must be transferred/sold to another band member ${ }^{142}$ Lastly, since certificates of possession are defined by legislation, they are enforceable in a court of law. ${ }^{143}$ However, certificates of possession and fee simple property rights are markedly different in other key respects.

The first crucial difference was mentioned earlier regarding the Indian Act's restrictions on to whom the certificate holder can sell or transfer their land; it must be to another band member. A landowner in dominant society by contrast, can sell or transfer their land to anyone as long as they are the age of majority. The next key difference exists in the fact that while a certificate holder possesses a legal interest to the land (the right to exclude other band members, to use the land, and to be compensated in instances of dispossession), they do not legally possess the underlying/reversionary title, which remains with the Crown. In other words, land held with a certificate of possession is still reserve land, and is thus inalienable in relation to non-Indian third parties. However, certificates of possession are not indefeasible. A certificate holder can still be dispossessed from their land, but only under certain circumstances, such as when a band council did not agree to issue the member a certificate; when the federal government expropriates reserve land under section 35 of the Indian Act; when the band surrenders

\footnotetext{
141 Woodward, Native Law, 278.

142 Woodward, Native Law, 279.

${ }^{143}$ Flanagan, Alcantara, and Le Dressay, Beyond the Indian Act, 93.
} 
reserve land to the Crown under section 38; and when the Minister on behalf of the band takes the land for the purposes set out in section 18(2) of the Indian Act (for example, to build a school). ${ }^{144}$

But with regards to reserve land's inalienability in relation to non-native third parties, most banks and other moneylenders have been known to be reluctant to lend money to certificate holders for this reason, since they cannot collect on the loan by repossessing the land incase of a default of payment. Due to the Indian Act, reserve land is safe from seizure. ${ }^{145}$ However, funding mechanisms have started to emerge in recent years (for instance, through the Canadian Mortgage and Housing Corporation, or the Bank of Montreal), which can assist certificate holders when starting up businesses, or helping them access mortgages to build or buy a home on a reserve. In these instances, the band guarantees the loan by taking on the certificate of possession as a form of collateral, and finalizes and awards the certificate of possession back to the band member once the loan and its interest have been paid off. ${ }^{146}$ To summarize then, certificates of possession provide band members with the benefits and responsibilities that are associated with fee simple land ownership, without the potential of have the land seized by non-native third parties.

\subsection{Private Property in Canada}

In general, property in Canada is best understood as a bundle of rights, as opposed to being a tangible thing. More specifically, it is a collection of rights over things/objects,

\footnotetext{
${ }^{144}$ Woodward, Native Law, 282.

${ }^{145}$ Flanagan, Alcantara, and Le Dressay, Beyond the Indian Act, 93.

${ }^{146}$ Flanagan, Alcantara, and Le Dressay, Beyond the Indian Act, 97.
} 
such as land, that are enforceable against others. ${ }^{147}$ According to Bruce Ziff, the bundle of rights that constitutes property includes the right to possess, manage, and control the thing/object; the ability to transfer the thing/object during one's lifetime and after death (through a will); and protection under the law against unjust dispossession by another citizen. ${ }^{148}$ Property also includes certain risks, or responsibilities, including liability to seizure, and lastly, the prohibition against harmful use. ${ }^{149}$

When extended to land, property can be owned collectively or by an individual, where the former is often described as public property, such as a park, where the government (federal, provincial, or municipal) often owns the land for the public's use. I should note that public property should not be confused with Indian reserve lands, which are completely different, with a different set of rules and rights relating to use and occupancy. That said, with respect to individual land ownership, it is made up of the same bundle of rights that were described earlier. In this case, a landowner possesses the right to use the land, dispose of the land through sale or through a will, and exclude others, all of which are enjoyed under the purview of the common law. However, they also risk expropriation, which can be enforced either by the state, or another party, such as bank.

Generally speaking, this is what fee simple ownership means, and according to Ziff, it is the closest thing to absolute ownership in the Anglo-Canadian system of landowning. ${ }^{150}$ The fact fee simple is considered 'the closest thing' to absolute ownership, as opposed to 'absolute' ownership, reflects the idea that the provincial or federal Crown

\footnotetext{
147 Bruce Ziff, Principles of Property Law (Toronto: Carswell, 2000), 2.

${ }^{148}$ Ziff, Principles of Property Law, 2.

${ }_{149}$ Ziff, Principles of Property Law, 3.

${ }^{150}$ Ziff, Principles of Property Law, 154.
} 
holds underlying/reversionary title, or radical title, to all of the lands across Canada, which means that in certain circumstances, such as in cases where the state possesses a right-of-way to construct hydro-electrical lines, the state can expropriate land from a person, as long as the landowner is compensated. ${ }^{151}$ According to Stephanie Farrington, this feature of Canadian property law is a remnant of the country's colonial heritage, when the colony decided to remain loyal to the British Crown during the Revolutionary War and the War of 1812. In exchange for their loyalty to the British Crown, colonists received security, although they also inherited a system of land ownership where the Crown possessed the underlying title to the land, and allowed citizens to live on the land with certain property rights. ${ }^{152}$ In modern terms, this has practical implications with respect to taxation or a person's vulnerability to expropriation.

The last aspect of private property/fee simple ownership that I feel needs to be discussed, particularly in light of the proposed First Nations Property Ownership Act, is its potential to lead to dispossession at the hands of third parties. While I already described how the state is legally permitted to expropriate land from the property owner, in this case I am referring to instances where a landowner puts up their property rights as collateral in order to access a bank loan/mortgage, and defaults on their payment schedule. In Canada, banks can foreclose on mortgages and repossess the property in order to make up for the debt, dispossessing a landowner from their property in the process. While there are mechanisms in place to protect the borrower from immediate dispossession, the threat

\footnotetext{
${ }^{151}$ Ziff, Principles of Property Law, 8.

${ }^{152}$ Stephanie Farrington, "Subject to Approval: Real Property Rights in Canada," Frontier Centre for Public Policy, accessed on December 12, 2012, http://www.yourlandisnotyourland.ca/YourLand_Summary/PS49_PropertyRights_F4NV012.pdf, 7.
} 
remains real, since it is an inherent risk that is associated with land/home ownership. ${ }^{153}$ Ultimately, while fee simple property rights give their owners greater access to loans and mortgages, dispossession is something many Indigenous communities are unwilling to risk, even though, as I will eventually explain, the $F N P O A$ would provide a mechanism that would supposedly prevent the erosion of a community's land base.

\section{PART 3: The Proposed First Nations Property Ownership Act}

\subsection{The Nisga'a Final Agreement}

To start this analysis, I should note the proposed FNPOA is inspired by the experience of the Nisga'a nation of northern British Columbia, who successfully negotiated the Nisga'a Final Agreement $(N F A)$ in 2000. As a result of these negotiations, the Nisga'a were entitled to financial compensation, jurisdiction and financial responsibility for a variety of social, political, and legal issues, underlying/reversionary title to 2,019 square kilometers of their traditional territory, ${ }^{154}$ ownership of sub-surface rights, and a series of other rights that are outlined in the Agreement. However, the $N F A$ also removed their collective Indian status, as well as their reserve status, including any protective measures that were contained in the Indian Act. ${ }^{155}$

That being said, the most interesting/controversial aspect of the $N F A$ is that it provided the Nisga'a with the jurisdiction to pass the Landholding Transition Act, which was enacted nine years later. Quite simply, the Landholding Transition Act gave Nisga'a

\footnotetext{
${ }^{153}$ Ziff, Principles of Property Law, 398-399.

${ }^{154}$ Aboriginal Affairs and Northern Development Canada, Fact Sheet: The Nisga'a Treaty, last modified September 15, 2010, http://www.aadnc-aandc.gc.ca/eng/1100100016428/1100100016429, accessed December 3, 2012.

${ }^{155}$ Flanagan, Alcantara, and Le Dressay, Beyond the Indian Act, 162.
} 
citizens the ability to own fee simple property rights within Nisga'a territory. ${ }^{156}$ While the land that was designated for private ownership only comprises a modest 10 square kilometers, an admittedly small fraction of their entire treaty land-base, this decision undoubtedly set the Nisga'a apart from other Indigenous nations, since they went down a path that was rarely entertained by other nations due to the historic association between private property and enfranchisement, assimilation, as well as its potential to lead to dispossession. However, according to the Nisga'a government, as well as the authors of Beyond the Indian Act, introducing private property to their community does not pose a threat to their land base, although they interestingly never addressed its assimilatory potential. $^{157}$

With regards to their claim that the Landholding Transition Act will not lead to dispossession, they point to the fact that the Nisga'a government possesses the underlying/reversionary title to the 2,019 square kilometers that were transferred to them according to the terms of the $N F A$. With the reversionary title, even if a Nisga'a citizen decides to sell their land to a non-Nisga'a person, or even decides to borrow money from a bank using their fee simple property rights to the land as collateral, and then defaults on their payments, the land will always remain Nisga'a land even if the individual no longer owns fee simple property rights to the parcel of land. If the bank wants to seize Nisga'a properties, it requires the Supreme Court of British Columbia's approval. ${ }^{158}$ In other words, while a Nisga'a citizen can lose their residency in the community due to an errant business plan or unpaid mortgage, which can lead to third parties gaining legal interests

\footnotetext{
${ }^{156}$ Andrew Findlay, "The Nisga'a's Private Struggle," BC Business Online, March 3, 2010, accessed January 6, 2013, http://www.bcbusiness.ca/real-estate/the-nisgaas-private-struggle, 1 .

${ }^{157}$ Flanagan, Alcantara, and Le Dressay, Beyond the Indian Act, 177.

${ }^{158}$ Union of British Columbia Indian Chiefs, "Plain Language Guide to the Nisga'a Agreement," 1998, accessed January 12, 2013, http://www.ubcic.bc.ca/files/PDF/nisgaaagreementplain.pdf, 14.
} 
in the community, the Nisga'a nation will always retain underlying title to the land. While this is supposed to be a comforting and defining feature of the $N F A$, the authors of Beyond the Indian Act admit that even with the reversionary title, there is still a rare possibility for the Nisga'a to be dispossessed entirely from their lands due to the fact that their collective interests to the land is still underlined by the Crown's title, who retained the right to expropriate Nisga'a land for the benefit of the general public. Because of this, in the rare chance the Nisga'a cease to exist as a people, or the province, or the country need land for whatever reason, any land that was expropriated would revert to the province of British Columbia. ${ }^{159}$

\subsection{The First Nations Property Ownership Act}

Before I start discussing the FNPOA, I need to clarify and mention a couple of things. First, this particular section of my thesis is simply going to discuss the legislation's technical elements; I will leave my critical analysis for the following section. Next, I should reiterate that the FNPOA is a developing, soon to be proposed, piece of legislation, and as such, I do not know what is actually contained in its pages. This does not mean however, that I am operating blindly. Instead, I am relying on the information that is contained in the book, Beyond the Indian Act: Restoring Aboriginal Property Rights, which contains a lot of details regarding the FNPOA, since it was specifically written to influence and shift Canadian Indian policy towards introducing this piece of legislation. $^{160}$

\footnotetext{
${ }^{159}$ Flanagan, Alcantara, and Le Dressay, Beyond the Indian Act, 162.

${ }^{160}$ Flanagan, Alcantara, and Le Dressay, Beyond the Indian Act, 7 and 161.
} 
With that said, to begin this discussion, I should note that the FNPOA is inspired by, and based upon the experience of the Nisga'a nation, who not only gained reversionary title to a portion of their traditional territory, but the Nisga'a nation also passed the Landholding Transition Act, which extended fee simple property rights to Nisga'a citizens. ${ }^{161}$ These two aspects- reversionary title and fee simple property rightsare the defining features of the proposed $F N P O A$, although this piece of legislation does contain other important elements.

For instance, since the FNPOA is being described as voluntary, in order for an Indigenous community to actually come under its jurisdiction, eligible community members would need to vote and meet a certain threshold that has yet to be determined, although it would be fair to assume it would require a majority of eligible community members vote in favour of adopting it. Regardless of the threshold, if a community does vote in favour of adopting the FNPOA, it would initiate the first major stage of the process, where the federal government, in collaboration with whatever province the community is situated in, would delegate the reversionary title from the Crown in the right of the province to the Indigenous community, which means that the community would gain the associated risks and responsibilities that accompany underlying title. ${ }^{162}$ After this, the community would likely need to pass a piece of legislation that asserts and protects their reversionary title, similar to the Nisga'a nation, who immediately after the NFA was established, passed the Nisga'a Land Title Act in May of 2000, which affirmed their underlying title. ${ }^{163}$

\footnotetext{
${ }^{161}$ Flanagan, Alcantara, and Le Dressay, Beyond the Indian Act, 161.

${ }^{162}$ Flanagan, Alcantara, and Le Dressay, Beyond the Indian Act, 169.

${ }^{163}$ Flanagan, Alcantara, and Le Dressay, Beyond the Indian Act, 162.
} 
Once passed, a community could start exercising its newly acquired jurisdiction, such as sub-dividing their land into individual plots, although if a community is uncomfortable with private property rights, they could forego extending fee simple property rights to its members, and simply grant them a 'lesser' legal interest to the land, such as leasehold tenure, which is a temporary property right. However, for communities that are interested in embracing private property, the FNPOA would reward them since it would be a fairly straightforward process to extend fee simple property rights to community members. According to the authors of Beyond the Indian Act, individuals who currently hold certificates of possession, or even individuals who possess a band council resolution to a parcel of customarily held land, could simply approach their Indigenous governments to transform their Indian Act property rights into fee simple rights. ${ }^{164}$

This transaction would need to be recorded in a community based lands registry, or more specifically, a Torrens style land registry. According to the authors, this type of registry is the most accurate and efficient way to record and guarantee title, since the certificate that is held in the registry is in itself proof of ownership; there is no need to do an extensive title search, which is the case with a deeds registry system. As a result, the need for lawyers to do a title search is eliminated, which reduces costs and waiting times associated with guaranteeing title. ${ }^{165}$ For these reasons, Flanagan and his coauthors state whether the community decides to subdivide their land base into fee simple holdings, or leasehold tenure, or a combination of both, a Torrens system registry would be an

\footnotetext{
${ }^{164}$ Flanagan, Alcantara, and Le Dressay, Beyond the Indian Act, 170.

${ }^{165}$ Flanagan, Alcantara, and Le Dressay, Beyond the Indian Act, 163.
} 
institution that every community that adopts the FNPOA would need to utilize. ${ }^{166}$ In other words, it is likely the proposed FNPOA contains a provision mentioning a Torrens style land registry.

To summarize, the FNPOA would transform an Indian reserve into a quasimunicipality, removing the community's reserve status, and likely removing their membership's collective Indian status, since many of the rights associated with Indian status are actually rights that must be exercised on a reserve. As a quasi-municipality, a community would possess more or less the same governing authority as a Canadian town or city. For instance, with underlying title and fee simple property rights, a First Nations government could start taxing its members, which would help establish and maintain infrastructure, a land code, zoning bylaws, a lands registry, and other municipal institutions that would make their communities save places for investment. According to the authors, the current system of Indian Act property rights deters economic development, since time limits (which are most associated with leases), insecure property rights (which are most associated with customary land holdings), and the inability to sell or transfer property rights beyond the boundaries of the reserve (which are most associated with certificates of possession) causes potential investors to second-guess their desire to invest in the community. In contrast, with fee simple property rights, a community could provide investment security, which would eventually help "unlock the tremendous economic potential of First Nations lands, to become productive contributors to the Canadian economy, and to provide a mechanism that will allow them to create the level of prosperity that other Canadians take for granted."167

\footnotetext{
${ }^{166}$ Flanagan, Alcantara, and Le Dressay, Beyond the Indian Act, 170.

${ }^{167}$ Flanagan, Alcantara, and Le Dressay, Beyond the Indian Act, 171-172.
} 


\subsection{Critical Analysis}

Before analyzing the First Nations Property Ownership Act, I need to establish this analysis' parameters, since the FNPOA provides plenty of points of entry that I could exploit and critique. For the sake of space and time and remaining consistent with this thesis' overall agenda, this analysis will try to only address my research question, which asks: why should Indigenous leaders reject this piece of legislation? In response, my thesis statement, or answer, was: Indigenous leaders should reject the FNPOA due to its similarities with the White Paper of 1969 , in the sense that both are/were premised on assimilation, and both can lead/could have led to the erosion of an Indigenous community's land base. Therefore, for this analysis, I will address each point in turn, starting with dispossession, and ending with a discussion on the legislation's assimilatory nature.

With regards to dispossession, as I already mentioned, the authors of Beyond the Indian Act are confident that giving First Nations underlying title to their communities will limit, if not completely prevent First Nations from being dispossessed from their lands. While I must admit that this is true in the sense that yes, the local government would possess underlying title to their lands, this becomes a less comforting detail when an individual's fee simple property rights are exposed to the free market. Considering the endemic poverty that exists in many communities, ${ }^{168}$ not to mention the current inability for some band members to even pay rent to the band council, let alone make mortgage payments to the Canadian Mortgage and Housing Corporation or other mortgage providers, it is worrisome that Flanagan and his coauthors, who acknowledged these

\footnotetext{
${ }^{168}$ Pam Palmater, Opportunity or Temptation? April 2010, accessed December 12, 2011 , http://reviewcanada.ca/reviews/2010/04/01/opportunity-or-temptation/.
} 
realities in extensive detail in their book, believe a private property regime would generate a better outcome.

Even the Nisga'a nation is experiencing difficulty with efficiently implementing its treaty agreement, considering a rather large portion of their compensation money (they received around $\$ 190-\$ 200$ million in 1999 dollars), has already been used to fund local social services, which used to be the federal government's responsibility. To some people, even within the Nisga'a nation itself, it is only a matter of time before the Nisga'a government begins selling fishing, timber, and mineral rights to non-native corporations in order to fund their government and social programs. If this happens, it would not take long until individuals and families start selling their plots of land out of sheer desperation in a community that has little economic potential. ${ }^{169}$ While $I$ am not suggesting that a mass exodus is likely to occur, at least not to the extent where every Nisga'a citizen moves away, it remains a possibility.

This is an unsettling reality in my opinion, and challenges the idea that the FNPOA guarantees land will always remain Indian land, since one must wonder if Indigenous people would still consider it to be 'Indian land' if non-native people, who purchased their right to live in the community, begin occupying parcels of land. In light of this, at what point does underlying title lose its meaning to Indigenous people themselves? At what point does it no longer provide a sense of security, considering an Indigenous person's right to reside in the territory/community ceases to be a treaty/Indian Act right, and instead becomes susceptible to the whims of the free market. In my opinion, underlying title is simply a distraction. It is a means to persuade native leaders who are

\footnotetext{
${ }^{169}$ Findlay, "The Nisga'a's Private Struggle," 4.
} 
able to dismiss the FNPOA's assimilatory potential, but are unsure about its potential to lead to the erosion of their community's land base.

Therefore, to the Indigenous leader who is unsure about the FNPOA in regards to dispossession: to assume that underlying title prevents dispossession is to believe in a half-truth. It is to believe a First Nation person's right to live in the community depends on their ability to pay taxes. It is to believe that as long as the First Nations government and bureaucracy is comprised of Indigenous people, it does not really matter who is residing in the community. It is to believe that being displaced by a bank as a result of an unpaid mortgage is perfectly legitimate, as long as the person who resides in the community after them is paying their mortgage, and paying taxes to the First Nations government. And finally, it is to ignore the fact the First Nations Property Ownership Act is modeled after the Nisga'a Final Agreement, which contains a provision that permits either the federal or provincial governments to expropriate land for the benefit of larger Canadian society. ${ }^{170}$ To assume the FNPOA will not include a similar provision is simply naïve.

While this might have come across as uncompromising, I was simply trying to make it clear that regardless of the legislation's stipulation regarding underlying/reversionary title, dispossession would still be inevitable. That being said, the issue of dispossession is a rather straightforward concept to discuss, considering its consequences are both physical and quantifiable. Simply put, dispossession is the loss of land. Assimilation on the other hand, is a fairly elusive concept to discuss, especially in relation to Indian policy, since it historically has cultural and legal implications. In light of this, my discussion on the issue of assimilation in relation to the FNPOA will focus on

\footnotetext{
${ }^{170}$ Union of British Columbia Indian Chiefs, "Plain Language Guide to the Nisga'a Agreement," 3.
} 
its similarities to the White Paper, which I should mention go beyond the fact they both advocate for introducing private property to Indian reserves. It is my opinion that drawing out their similarities will highlight how the FNPOA is designed, like the White Paper was, to assimilate Indigenous people.

As I described earlier in this chapter, the authors of the White Paper attempted to justify the shift in Indian policy by pointing out how the Indian Act made on-reserve economic development difficult, if not completely impossible. More specifically, the authors of the White Paper identified the Indian Act's ineffectual property rights, a cumbersome bureaucracy, and a lengthy approval process as the primary reasons for not only introducing fee simple property rights, but also as a justification to eliminate the Indian Act. Similarly, the authors of Beyond the Indian Act also point to the Indian Act's inefficient system of property rights as the main reason why both the FNPOA is needed, although the FNPOA, if enacted, would not take the same unilateral approach as the White Paper. ${ }^{171}$ As I described earlier, the FNPOA would be a voluntary measure. In other words, while their approach towards implementation might be different, both documents are/were 'needed' for the same reason: to free Indians from the oppressive Indian Act so that they can participate in the economy.

The last comment is important to take into consideration, since both the White Paper and the FNPOA are premised on liberation, in the sense that they were both designed to free Indigenous people from the shackles of the Indian Act's oppression. This idea was evident throughout the White Paper's pages, much like it is evident throughout Flanagan et al.'s book. It seems however, the authors of both documents take different approaches towards liberating Indigenous peoples.

\footnotetext{
${ }^{171}$ Flanagan, Alcantara, and Le Dressay, Beyond the Indian Act, 4.
} 
As Dale Turner identified, the authors of the White Paper thought the best way to liberate Indian people from the impoverished space they occupied on the margins of society was to extinguish their special rights and make them 'equal' citizens, in a topdown, unilateral fashion. ${ }^{172}$ In contrast, the authors of Beyond the Indian Act approach liberation in a less paternalistic manner, but with the same assimilatory attitude. For example, Tom Flanagan and his coauthors suggest in the introduction to their book that any Indigenous community that is interested in embracing private property should be given the chance; they should not be denied this opportunity. ${ }^{173}$ This is supposed to reflect a grassroots approach to Indian policy, since a community's agency is supposedly being respected. However, in actuality, this approach is delegating responsibility for native poverty/social pathologies onto the community, since it implies that if a community rejects this liberating proposal, they are responsible for their own marginalized reality since they are not accepting the gift of freedom the FNPOA is supposed to represent. In other words, the authors are placing the blame for Indigenous poverty on Indigenous people and their leaders. While blaming Indians for the pathologies that exist in their communities is simply ignorant of history, it reflects a growing trend in mainstream society and how they view/discuss Indigenous issues. Within this discourse, colonialism does not exist, nor does its intergenerational effects; rather, Indigenous poverty and other social pathologies exist in a vacuum.

This idea is reflected multiple times in Beyond the Indian Act, although it is not reflected in the words that were written, but rather in what was omitted. Quite simply, none of the book's authors describe how the history of colonialism in Canada has

\footnotetext{
${ }^{172}$ Turner, This is not a Peace Pipe, 29.

${ }^{173}$ Flanagan, Alcantara, and Le Dressay, Beyond the Indian Act, 5.
} 
generated the poverty and/or social pathologies that exist in Indigenous communities, which is an issue that legal scholar Pam Palmater highlighted in her review of their book. ${ }^{174}$ While this omission is problematic in its own right, it becomes even more problematic when the authors of Beyond the Indian Act insinuate that Indigenous people created and are responsible for their own present day realities. In the tenth chapter, for instance, after the authors describe the First Nations Property Ownership Act's technical elements, Flanagan and his coauthors answer the rhetorical question as to which First Nations communities might be interested in the FNPOA, and they suggest communities that are innovative, that want to increase the values of their lands, and want to reduce transaction costs associated with economic development. In their own words, "many if not most First Nations would potentially be interested in this legislation." 175

By making the criteria as general as possible, and then suggesting every community might be interested in this piece of legislation, the authors cleverly created a false dichotomy, where those communities who might 'see the light' and are willing to embrace private property become innovative and progressive, while those who reject the FNPOA become backwards, and are embracing their own marginalized existence. But what does this have to do with my claim that the FNPOA is promoting assimilation, considering it would take a completely different approach than the White Paper did in terms of implementing the proposal? Moreover, how will the FNPOA lead to assimilation if it is up to the community to decide if they will adopt it?

The answer to these questions is fairly straightforward: it has less to do with the approach that is taken, but rather the consequence of adopting the FNPOA. Just like the

\footnotetext{
${ }^{174}$ Palmater, Opportunity or Temptation?

${ }^{175}$ Flanagan, Alcantara, and Le Dressay, Beyond the Indian Act, 177-178.
} 
White Paper, the FNPOA is designed without any historical context or understanding of colonialism. Had the authors/developers recognized colonialism's impact on present day realities, it could be argued that their proposal is an appropriate mechanism to address historical grievances, much in line with Roger Maaka and Augie Fleras' observation that policies that impact Indigenous people must address the things that Indigenous people actually want and need. More specifically, it should respond to the needs of communities in a culturally appropriate manner. ${ }^{176}$

Unfortunately, the FNPOA does not do this. Instead, it is designed to integrate (assimilate) Indians into mainstream society, strip them of their Indian status, and give them the same rights and responsibilities as 'other Canadians.' Moreover, just like the White Paper and the enfranchisement provisions that preceded it, private property would play an integral role in this process, since by giving Indigenous people the possibility to participate in the economy on an equal playing field, it would reduce, if not completely eliminate the department's fiduciary duty, since fee simple property rights are supposed to create self-sufficient communities through taxation. In other words, it could achieve the same results the White Paper would have achieved, had it been enacted, thus fulfilling Indian policy's long-term agenda.

\footnotetext{
${ }^{176}$ Fleras and Maaka, "Indigeneity Grounded Analysis as Policy (-Making) Lens," 21.
} 


\section{Chapter Four: Summary of Findings and Recommendations}

\section{PART 1: Summary of Findings and Concluding Remarks}

\subsection{The Evolution of my Rationale to Complete this Project}

When I first read Tom Flanagan's book, Beyond the Indian Act: Restoring Aboriginal Property Rights in 2010, it did not occur to me that the federal government would act upon its recommendation to introduce fee simple property rights to First Nations reserves. In fact, even when I decided to write this thesis in 2011 , it still did not occur to me that the federal government would attempt to introduce private property to First Nations reserves, especially in light of the numerous times that similar proposals and policies were rejected in the past.

This sense of assurance framed my initial research, and the way I wanted to approach this academic project, since I had planned to simply critique the ideological underpinnings of Beyond the Indian Act, and draw out the connections between it and Tom Flanagan's other book, First Nations? Second Thoughts, in order to demonstrate that Flanagan still believes Indigenous people need to assimilate into mainstream society. However, when I heard in 2012 that the federal government was actually developing the First Nations Property Ownership Act as it is described in the book Flanagan coauthored, I understood that my research and the overall purpose of my thesis needed to adjust accordingly. Therefore, I reframed my research, and asked a new question: why should Indigenous leaders and communities reject the FNPOA? 
This question reflected the new context, or new political reality that surrounded my thesis; I no longer had the luxury to perform an intricate intellectual exercise by critiquing the book. While I believe that such an academic endeavor would have been useful, I wanted my thesis to be more practical, and engage the FNPOA directly. Moreover, I wanted to produce an accessible and relevant thesis to serve as a resource for Indigenous communities to understand why they should reject the proposed legislation. More than anything however, I wanted to appeal to Indigenous leaders, since if they are given the proper tools, information being one of them, they have the potential to undermine the state's assimilatory agenda through their decisions and actions. ${ }^{177}$

\subsection{Summary of Findings}

I approached this thesis from the point of view that an Indigenous leader's ability to either accept or reject the FNPOA must be guided by appropriate and accurate information, which is why I wanted my thesis statement to be as straight to the point as possible, since like my research question, it would frame how I articulated my thoughts. Therefore, my thesis statement was: Indigenous leaders should reject the FNPOA due to its similarities with the White Paper of 1969 , in the sense that both promote assimilation, and both can lead to the erosion of an Indigenous community's land base.

From this point forward, my thesis addressed these two ideas, although I did not immediately start discussing the White Paper of 1969 , let alone the FNPOA, which were both discussed in my third chapter. Instead, I used the second chapter to contextualize both the White Paper and the FNPOA, describing how since the early to mid nineteenth

\footnotetext{
${ }^{177}$ Taiaiake Alfred, Peace, Power, Righteousness: An Indigenous Manifesto, 2nd Edition (Don Mills, Ontario: Oxford University Press, 2009), 100.
} 
century, church and state officials have consistently urged Indians to adopt private property rights.

As I discussed in my second chapter, introducing private property to reserves has been an important aspect of Canada's Indian policy since at least 1857, when the Gradual Civilization Act was enacted. While less formal attempts to introduce a form of individual land tenure were attempted prior to this, the Gradual Civilization Act marked the first time that it was codified into law. As I explained, this Act was the first piece of legislation that associated private property rights with legal assimilation, also known as enfranchisement, which was a new legal concept, whereby an Indian male could voluntary give up his Indian status/legal Indigenous identity in order to become a citizen of the colony, and as a result, gain a life estate to a portion of reserve land.

The colonial government saw enfranchisement as the best way to assimilate Indians, abolish the reserve system, eliminate their costly financial responsibility, and open up reserve land for white settlement-one enfranchised Indian at a time. This approach, however, proved to be a failure, since Indians simply had no desire to enfranchise. Despite its rejection, enfranchisement was carried over into the Gradual Enfranchisement Act of 1869, as well as into the Indian Act, until enfranchisement in general was finally eliminated from the Indian Act in 1985.

As my second chapter illustrated, it was during the time period between 1876 and 1985 that saw the most changes in enfranchisement policy. In this 109 -year period, new provisions and standards for enfranchisement were introduced to the Indian Act as a way to respond to the resistance that communities were displaying against it. For instance, compulsory enfranchisement was introduced in the first Indian Act in 1876 after 
voluntary enfranchisement proved to be ineffective in the previous few decades. However, voluntary enfranchisement was still included in the 1876 Indian Act, which reflected the department of Indian Affairs' hope that its other social and political initiatives, such as the residential school system, the location ticket, the certificate of possession, and the band council, in conjunction with ongoing Christianization, would gradually change the Indian's heart and make them want to enfranchise on their own. However, as I discussed, this simply did not happen. Instead, it was compulsory enfranchisement that generated the most cases of Indians losing their Indian status, particularly through 'marrying-out' provisions, which targeted native women who married non-Indian men. These women however, did not gain fee simple property rights to reserve land.

The other enfranchisement provision that I discussed, which existed in every version of the Indian Act until 1985, was the community-wide enfranchisement provision. This provision existed in both voluntary and involuntary forms, and when it was applied once in the 1880s, and then again in 1958 , it enfranchised every single band member within the communities that adopted it, turning each person into a non-Indian Canadian citizen. In retrospect, community-wide enfranchisement is actually the most similar to the FNPOA, even more so than the White Paper, since it only applied to communities that chose to enfranchise, while the White Paper would have turned every single Indian across Canada into a Canadian citizen, with no Aboriginal or treaty rights. With that being said, my third chapter analyzed the White Paper for a reason.

Besides its obvious similarity with the First Nations Property Ownership Act in terms of introducing private property, the White Paper was also justified for the same reasons. For instance, it was described as an alternative to the current Indian Act system, 
since its developers argued that the Indian Act gave Indigenous people limited access to things that 'every other Canadian' took for granted, such as fee simple property rights, or access to mortgages and bank loans. The White Paper also defined itself as a liberating force, suggesting that it possessed the answers to address the living conditions many Indians found themselves in after a century of colonialism. Interestingly, the White Paper never actually mentioned or addressed colonialism, much like Beyond the Indian Act never mentioned the historical legacy of legalized racism, marginalization, and oppression. ${ }^{178}$ Instead, the White Paper presented its proposal in a vacuum, unaffected by history. Thankfully, as I described in my third chapter, the White Paper was never enforced, since Indigenous people saw through its liberal rhetoric, and protested against its intentions to implement the same assimilatory agenda that defined the previous century. While it was not enforced, its underlying motives and assumptions still live on to this day, as my discussion on the FNPOA illustrated.

After I discussed the White Paper, I shifted my focus in the third chapter and discussed the FNPOA as it was described in the book, Beyond the Indian Act. First however, I described how it was modeled after the Nisga'a Final Agreement, which was finalized in 1999. I then went on to discuss the FNPOA, and mentioned if adopted by an Indigenous community, the FNPOA would transfer underlying/reversionary Crown title to the community, and literally transform an Indian reserve into a quasi-municipality, complete with many of the same legal features, jurisdictions, and responsibilities that come with municipal status. For instance, a First Nations community that adopts the FNPOA would cease to be a reserve under the Indian Act. However, since no longer under the Indian Act, this community would be able to implement its own tax regime, as

\footnotetext{
${ }^{178}$ Palmater, Opportunity or Temptation?
} 
well as create and enforce its own land code and associated bylaws. Most importantly, a community would be able to extend and guarantee fee simple property rights to its citizens. According to the authors, the fact a community would gain underlying title should set the minds of its leaders and its community members at ease regarding the possibility of alienating their land-base through expropriation or dispossession, since the underlying title would always remain in the possession of the First Nations government.

As I suggested in my critique however, if the FNPOA is truly based on the Nisga' a Final Agreement, the idea of security against expropriation is only half-correct, since not only would the federal and provincial governments maintain the right to expropriate land, but a third party, such a bank- if it had to- could get a Provincial Supreme court to issue an injunction to seize assets, especially in a community's residential area. ${ }^{179}$ It is important to note however, that some areas of the community would be safe from seizure altogether if the FNPOA is truly like the Nisga'a agreement, since certain Nisga'a lands are safe from seizure as long as the Nisga'a government does not grant any sort of interest to the land, like fee simple property rights. In this case, the land would remain the property of the Nisga'a government. ${ }^{180}$ That being said, while it appears some land under the FNPOA would be safe from being seized or expropriated, what is not up for debate is this legislation's potential to assimilate a community that chooses to adopt it.

As I explained in my third chapter, the FNPOA does not only contain most of the same technical elements as the 1969 White Paper, but it is also motivated by the same ideas, assumptions, and ideologies. For instance, the developers of the FNPOA assume,

\footnotetext{
${ }^{179}$ Union of British Columbia Indian Chiefs, "Plain Language Guide to the Nisga'a Agreement," 14.

${ }^{180}$ Union of British Columbia Indian Chiefs, "Plain Language Guide to the Nisga'a Agreement" 3.
} 
like the White Paper's developers assumed, that this proposal has the potential to free Indians from their state of poverty and economic dependency. Moreover, it also assumes, much like the White Paper did, that Indians want to become individualistic, landowning citizens of Canada. But most importantly, outside its assumptions, the FNPOA has the potential to accomplish what the White Paper tried to do: eliminate a community's reserve status, abolish their collective Indian status, and assimilate/integrate an entire community into Canadian society. There is simply no denying these facts.

Therefore, to conclude this summary, I should reiterate that Indigenous leaders and communities must reject the First Nations Property Ownership Act due to the simple fact it is a reformulated version of the White Paper. Personally, I find this truly discouraging and insulting, since it means that Indian policy makers are still trying to implement the same assimilatory agenda that was established in the nineteenth century: assimilate Indians, and turn them into land-owning citizens so that dominant society can access their lands and resources.

While the FNPOA is not as abrupt and oppressive as those historic policies and provisions, the fact Tom Flanagan and his coauthors, and not to mention the Aboriginal Affairs bureaucrats that are currently developing the FNPOA, are trying to suggest this represents a fresh start is insulting to Indigenous people. It is insulting because it means they believe we deserve nothing more than the freedom and security that private property rights are supposed provide. It is also insulting since it suggests the Canadian state has never taken our consistent demands for treaty implementation and a true nation-to-nation relationship seriously. However, Indigenous people should not take this as a sign that things will never change. I still have hope for our future. 


\section{PART 2: Recommendations}

\subsection{The Mohawk Prophecy of the Two Headed Snake}

The reason I am optimistic for the future is because I believe, despite the setback the FNPOA represents- especially if it is enacted-Indigenous people are on the cusp of a revolution. I say this in light of a prophecy I heard when I was a young boy that describes a period of time defined by oppression and destruction, which is followed by a time of struggle, resilience, and finally strength and happiness. The prophecy goes something like this:

"One day, a young boy had found a two-headed serpent (snake) whose skin had beautiful colors with gold and silver stripes down its back; but it was very sickly, unable to care for and feed itself. It was on the very door of death. This was due to the fact that one head wanted to go left while the other wanted to go right. One wanted to move while the other wanted to stay still. Basically, one head didn't know what the other was doing."

"The young boy brought the serpent to his village. The elders were very cautious of it but everyone loved its beautiful colors and felt sorry for it. The young ones said, 'It's so poor. How will it survive? Look at how helpless it is. Surely it will die with the coming of winter. Please let us keep it?' The elders agreed, saying "OK you can keep it but not in the house, and remember: if you want to keep it, you will have to feed it!"

"The children fed it insects but the snake wanted more so they fed it field mice, but the snake wanted more. They fed it rabbits and small birds but the snake wanted more! Finally, with this serpent getting so big, the elders began hunting our brothers, the beavers and otters, to feed the snake; but this snake didn't seem to get enough."

"The serpent began eating our dogs, then our food supply - the gardens and the deer, then all our spirit guides. When that was not enough, the serpent finally began eating our people. It ate the children, the elders and any who were not fast enough to get away. So horrible was this serpent that it even ate our dead - something that our people had never seen."

"Then this two-headed serpent began eating whole villages and in the process, it enslaved many of the people. Then it started traveling the countryside looking for more villages to eat. Along the way, it started eating anything in its path - the forest, all the animals and the countryside itself. It ate holes through mountains that were in its way and it poisoned our waters with its defecation." 
"After traveling the entire country, it began to back-track to totally destroy the land by poisoning anything that may have been undisturbed. All the animals were completely poisoned, as was the ground. The forests that were missed were now devoured, the waters that were not damaged were now completely poisoned also."

"Finally, after our Mother Earth was destroyed and there was nothing left for the two headed serpent to consume, it then started to eat into the Sky World. It was said that it would make its way out to our Grandmother, the night-time sun (the moon), and that it would even try to destroy our Eldest Brother, the sun, and that from there it would attack all our cousins, the stars. But it was also said that when the serpent would be near the end of its destruction of our Mother Earth that the Earth would fight back to cleanse herself."

"This is when a young boy would come again and with the power of the hair of the clan mothers, would make a bow that would thrust his arrows straight and true into the heads of the two-headed serpent. When the serpent rolls over and dies it is said that the young boy will climb atop the huge monster's belly and in slicing it open, all the real people who were eaten up will have been released."

"When the serpent is destroyed, all life will once again live in freedom the way the Great Spirit had intended and creation itself will blossom with a new vibrancy that has not been seen since the coming of the serpent."

When interpreting the prophecy, it is quite obvious that collectively, Indigenous people are still living in the stage before the boy kills the snake. While I already mentioned it is a time defined by oppression and continued attempts to destroy the land and our nations, it is also a time of increasing awareness, reawakening, and at times, resilience. I say resilience because at various points in our history, we could have been completely destroyed, but we are still here. But we are still being oppressed, and like the story implies, we wait for the day when the boy will rise up and kill the snake.

Therefore, as I prepare to make my recommendations, I must remember the prophecy and its implications on this thesis. While I do not assume that this thesis in any way represents the young boy who kills the snake, since I genuinely believe it symbolizes a collective act of resistance against the state's tyranny through active and aggressive

${ }^{181}$ Dave Star, Two-Headed Serpent Prophecy of the Haudenausonee, last modified September 6, 2004, accessed September 23, 2011, http://www.indigenouspeople.net/twohead.html. 
behaviours, which does not necessarily constitute violence, I do believe this thesis is part of the reawakening process that takes place before the boy rises up.

\subsection{Recommendations}

My recommendations are fairly straightforward, and like my thesis statement, they are directed towards Indigenous leaders, and to a lesser extent, other Indigenous academics. I am expressing them with a sense of urgency however, since it is likely the First Nations Property Ownership Act will be enacted by Parliament, considering the Conservative Party of Canada not only mentioned they are interested in enacting this legislation, ${ }^{182}$ but also because they hold a majority in the House of Commons.

\section{Recommendation 1: Reject the FNPOA}

The first recommendation is premised on the fact the First Nations Property Ownership Act will be voluntary. Given this flexibility, I urge band councils, traditional chiefs, and other cultural leaders in Indigenous communities, especially in communities that might be interested in adopting the FNPOA, to raise awareness so that they can collectively resist and reject the FNPOA for the reasons outlined in the previous two chapters of this thesis regarding dispossession and assimilation. However, I am also urging Indigenous leaders to reject the FNPOA for another reason that was not explained in the previous chapters, since it falls outside of the scope of my thesis statement. Instead, it is related to the prophecy I just outlined.

\footnotetext{
${ }^{182}$ Bill Curry, "Ottawa Proposes First Nations Property Ownership," The Globe and Mail, September 6, 2012, accessed September 8, 2012, http://www.theglobeandmail.com/news/politics/ottawa-proposes-firstnations-property-ownership/article4181157/.
} 
Since Indigenous people exist at the point in time before the young boy rises up and kills the snake, which symbolizes our collective will to throw off our oppression that will inevitably lead into a period of resistance, confrontation, and struggle, I am recommending that Indigenous leaders remain vigilant and protect our communities so that we have the physical space to decolonize. Indigenous scholars Taiaiake Alfred and Jeff Corntassel refer to this space as a 'zone of refuge,' where Indigenous ideas, epistemologies, languages, identities, and our overall sense of self- our 'onwehonweneha' in the Mohawk language- is protected from the forces of imperialism and colonialism. ${ }^{183}$ In their opinion, maintaining our onknwehonweneha is integral to our survival, since it provides us with strength, and can provide a foundation to initiate the decolonizing resistance that has been prophesied to take place. ${ }^{184}$ Granted our communities are not sheltered from every conceivable neocolonial force, adopting the FNPOA and implementing a private property regime would not be conducive to protecting those zones of refuge.

Not only would the FNPOA remove important legal mechanisms that protect our land base from third parties and provincial governments- protections that first appeared in the Royal Proclamation of 1763 , a document that recognized our sovereignty- but adopting the FNPOA would also imply that we are 'asking for' the individualism, greed, and other associated values that come with private property. ${ }^{185}$ Even Tom Flanagan and his coauthors acknowledge their proposal's potential to generate this kind of cultural shift, going so far as to say they realize the First Nations Property Ownership Act would

183 Jeff Corntassel and Taiaiake Alfred, "Being Indigenous: Resurgences against Contemporary Colonialism," Government and Opposition: An International Journal of Comparative Politics (2005), 605.

${ }^{184}$ Taiaiake Alfred, Wasase: Indigenous Pathways of Action and Freedom (Peterborough: Broadview Press, 2005), 56.

${ }^{185}$ Corntassel and Alfred, "Being Indigenous," 609. 
undoubtedly "create more Indian millionaires. We don't apologize for that; every community should have successful entrepreneurs, whose economic leadership creates jobs and opportunities for others."

In other words, Flanagan et al. realize their proposal is embedded within the neoliberal, profit-driven, consumerist culture that defines Canadian society, and are uncompromisingly unapologetic about its potential to lead to further inequality and cultural erosion in Indigenous communities. In light of their statement, I would argue that our communities do not need more millionaires. We need to restore our languages and cultural traditions, so that we can know what it means to be Indigenous in a nation-tonation relationship with Canada, and not live according to the expectations and standards that Canadian society has created for us.

\section{Recommendation \#2: Further Research}

While this thesis attempted to accurately describe the historic relationship between Indians, enfranchisement/assimilation, and private property/fee simple, there were issues that simply fell outside of this thesis' scope. For instance, one of the most important issues that I never had the opportunity to discuss, at least not in detail, is how the FNPOA will potentially affect treaty rights. Considering the eternal nature of the treaty relationship, it would be useful for academics, especially within the legal community, to explore the interplay between treaties and the FNPOA. While its developers are adamant that First Nations underlying/reversionary title would protect a community's land base, as I described in chapter three, dispossession by the state and by third parties is still a potential risk. In instances like this, would enforcing the FNPOA infringe on the treaty

\footnotetext{
${ }^{186}$ Flanagan, Alcantara, and Le Dressay, Beyond the Indian Act, 6.
} 
right to reserve land in the more specific context of the right to reside on a reserve, or would the band's possession of underlying title be sufficient in a court's opinion? Stated another way, would the FNPOA infringe on an individual Indian's treaty right to live on the reserve if they were dispossessed of their fee simple property rights by a bank?

Unfortunately, this kind of research faces a serious challenge, in the sense that being able to fully understand the First Nations Property Ownership Act's potential to infringe on treaty rights is still unknown. We will only have a better understanding after it is enacted, and arguably, after it is adopted by a First Nations community. It is my hope however, that we never have to analyze its impact on a community, since its potential to lead to dispossession in itself should cause concerns within the larger Indigenous community, not to mention its near guarantee to lead to the cultural and legal assimilation of those communities that might adopt it.

\section{Bibliography}

Aboriginal Affairs and Northern Development Canada. Fact Sheet: The Nisga'a Treaty. September 15, 2010. http://www.aadnc-aandc.gc.ca/eng/1100100016428/1100100016429 (accessed December 3, 2012).

Alcantara, Christopher and Tom Flanagan. "Individual Property Rights on Canadian Indian Reserves," Fraser Institute. August 12, 2002.

http://www.fraserinstitute.org/research-news/display.aspx?id=13114 (accessed October $25,2012)$.

Alfred, Taiaiake. Peace, Power, Righteousness: An Indigenous Manifesto, (2nd Edition). Don Mills, Ontario: Oxford University Press, 2009.

-. "Warrior Scholarship: Seeing the University as a Ground of Contention." In Indigenizing the Academy: Transforming Scholarship and Empowering Communities, by Devon A. Mihesuah and Angela Wilson (editors), 88-99. Lincoln: University of Nebraska Press, 2004. 
-. Wasase: Indigenous Pathways of Action and Freedom. Peterborough: Broadview Press, 2005.

Borrows, John. Canada's Indigenous Constitution. Toronto: University of Toronto Press, 2010.

-. "Wampum at Niagara: The Royal Proclamation, Canadian Legal History, and SelfGovernment." In Aboriginal and Treaty Rights in Canada: Essays on Law, Equality, and Respect for Difference, by Michael Asch (editor), 155-172. Vancouver: UBC Press, 1997.

Cardinal, Harold. The Unjust Society. Seattle: University of Washington Press, 1999.

Chiefs, Union of British Columbia Indian. "Plain Language Guide to the Nisga'a Agreement." 1998, accessed January 12, 2013, http://www.ubcic.bc.ca/files/PDF/nisgaaagreementplain.pdf.

Corntassel, Jeff and Taiaiake Alfred. "Being Indigenous: Resurgences against Contemporary Colonialism." Government and Opposition: An International Journal of Comparative Politics, September 2005: 597-614.

Curry, Bill. "Ottawa Proposes First Nations Property Ownership." The Globe and Mail, September 6, 2012, accessed September 8, 2012, http://www.theglobeandmail.com/news/politics/ottawa-proposes-first-nations-propertyownership/article4181157/.

Dickason, Olive Patricia. Canada's First Nations: A History of Founding Peoples from Earliest Times. Don Mills: Oxford University Press, 2002.

Farrington, Stephanie. "Subject to Approval: Real Property Rights in Canada." Frontier Centre for Public Policy. April 1, 2008, accessed December 12, 2012, http://www.yourlandisnotyourland.ca/YourLand_Summary/PS49_PropertyRights_F4NV 012.pdf.

Findlay, Andrew. "The Nisga'a's Private Struggle." BC Business Online. March 3, 2010, accessed January 6, 2013, http://www.bcbusiness.ca/real-estate/the-nisgaas-privatestruggle.

Flanagan, Tom. First Nations? Second Thoughts. Montreal and Kingston: Mcgill-Queen's University Press , 2000.

Flanagan, Tom, Christopher Alcantara, and Andre Le Dressay. Beyond the Indian Act: Restoring Aboriginal Property Rights. Montreal-Kingston: McGill-Queen's University Press, 2010.

Government of Canada. Royal Commission on Aboriginal Peoples. Royal Commission, Ottawa: Government of Canada, 1996. 
- Statement of the Government of Canada on Indian Policy 1969. Report on Indian Policy, Ottawa: Government of Canada, 1969.

Lawrence, Bonita. "Rewriting Histories of the Land: Colonization and Indigenous Resistence in Eastern Canada." In Race, Space, and the Law: Unmapping a White Settler Society, by Sharene H. Razack, 21-46. Toronto: Between the Lines, 2002.

Leslie, John F. "The Policy Agenda of Native Peoples from WW2 to the 1969 White Paper." In Aboriginal Policy Research: Setting the Agenda for Change (Vol. 1), by Jerry P. White et al. (editors), 15-28. Toronto: Thompson Education Publishing, 2004.

Maaka, Roger and Augie Fleras. "Indigeneity-Grounded Analysis (IGA) as Policy (Making) Lens: New Zealand Models, Canadian Realities." The International Indigenous Policy Journal, 2010: 1-34.

Miller, J.R. "'And whereas it is just and reasonable...': The Royal Proclamation and the Upper Canadian Treaties." In Compact, Contract, Covenant: Aboriginal Treaty-Making in Canada, by J.R. Miller, 66-92. Toronto: University of Toronto Press, 2009.

-. "From Alliance to Irrelevance." In Skyscrapers Hide the Heavens: A History of Indian-White Relations in Canada 3rd Ed., by J.R. Miller, 103-124. Toronto: University of Toronto Press, 2000.

-. "Reserves, Residential Schools, and the Threat of Assimilation." In Skyscrapers Hide the Heavens: A History of Indian-White Relations in Canada, by J.R. Miller, 125-147. Toronto: University of Toronto Press, 2000.

-. "The Beginnings of Political Organizations." In Skyscrapers Hide the Heavens: $A$ History of Indian-White Relations in Canada, by J.R. Miller, 311-335. Toronto: University of Toronto Press, 2000.

-. "The Policy of the Bible and the Plough." In Skyscrapers Hide the Heavens: A History of Indian-White Relations in Canada, by J.R. Miller, 255-282. Toronto: University of Toronto Press, 2000.

-. "There is no end to relationship among the indians': Early Commercial Compacts." In Compact, Contract, Covenant: Aboriginal Treaty-Making in Canada, by J.R. Miller, 3-32. Toronto: University of Toronto Press, 2009.

Milloy, John S. A National Crime: The Canadian Government and the Residential School System 1879 to 1986. Winnipeg: The University of Manitoba Press, 1999.

Palmater, Pam. Opportunity or Temptation? April 2010, accessed December 12, 2011, http://reviewcanada.ca/reviews/2010/04/01/opportunity-or-temptation/. 
Place, Jessica and Brian Egan. "Minding the Gaps: Property, Geography, and Indigenous Peoples in Canada." Geoforum, January 2013: 129-138.

Star, Dave. Two-Headed Serpent Prophecy of the Haudenausonee. September 6, 2004, accessed September 23, 2011, http://www.indigenouspeople.net/twohead.html.

Tobias, John. "Protection, Civilization, Assimilation: An Outline History of Canada's Indian Policy." In Sweet Promises: A Reader on Indian-White Relations in Canada, by J.R. Miller (editor), 127-143. Toronto: University of Toronto Press, 1991.

Turner, Dale. This is not a Peace Pipe: Towards a Critical Indigenous Philosophy. Toronto: University of Toronto Press, 2006.

Wilson, Shawn. Research is Ceremony: Indigenous Research Methods. Halifax and Winnipeg: Fernwood Publishing, 2008.

Woodward, Jack. Native Law. Scarborough: Carswell Thomson Professional Publishing, 2007.

Wright, Ronald. Stolen Continents: Conquest and Resistance in the Americas. Toronto: Penguin Group, 2003.

Ziff, Bruce. Principles of Property Law. Toronto: Carswell, 2000. 